\title{
Neurotransmitter Profile of Saccadic Omnipause Neurons in Nucleus Raphe Interpositus
}

\author{
Anja K. E. Horn,' Jean A. Büttner-Ennever, ${ }^{1}$ Petra Wahle, ${ }^{2}$ and Ingrid Reichenberger ${ }^{3}$ \\ IInstitute of Neuropathology, University of Munich, 80337 Munich, ${ }^{2}$ Department of Zoology and Neurobiology, ND7/31 \\ Ruhr-University, 44700 Bochum, and 3 Institute of Physiology, University of Munich, 80336 Munich, Germany
}

\begin{abstract}
Saccadic omnipause neurons (OPNs) are essential for the generation of saccadic eye movements. In primates OPNs are located near the midline within the nucleus raphe interpositus (rip). In the present study we used several different neuroanatomical methods to investigate the transmitters associated with OPNs in the monkey. Immunolabeling for the calcium-binding protein parvalbumin was employed to mark OPNs in the monkey and define the homologous cell group in cat and human. The use of antibodies against GABA, glycine (GLY), glutamate (GLU), serotonin (5-HT), and tyrosine hydroxylase revealed that the somata of OPNs are GLY immunoreactive, but they are devoid of GABA and 5-HT immunostaining. In situ hybridization with the $\mathrm{GAD}_{67}$ mRNA probe confirmed the negative GABA immunostaining of OPNs. ${ }^{3} \mathrm{H}-\mathrm{GLY}$ was injected into a projection field of OPNs, the rostral interstitial nucleus of the medial longitudinal fascicle (riMLF) - the vertical saccadic burst neuron area. This resulted in selective retrograde labeling of the OPNs in rip, while no labeling was found in the superior colliculus, which sends an excitatory projection to the riMLF. The somata and dendrites of putative burst neurons in the riMLF were contacted by numerous GLY-immunoreactive terminals.

The quantitative analysis of immunoreactive terminal-like structures contacting OPNs revealed a strong input from GLY-and GABA-positive terminals on somata and dendrites, whereas GLU-positive puncta were mainly confined to the dendrites. Very few 5-HT and catecholaminergic terminals contacted OPN somata. Our findings suggest that OPNs use GLY as a neurotransmitter, and they receive numerous contacts from GABAergic, glycinergic, and glutaminergic afferents, and significantly fewer from monoaminergic inputs.
\end{abstract}

IKey words: saccadic eye movement, omnipause neurons, nucleus raphe interpositus, glycine, GABA, glutamate, 5-HT, catecholamines, parvalbumin, in situ hybridization]

Received May 17, 1993; revised Sept. 14, 1993; accepted Sept. 21, 1993

We are grateful for the generous supply of the GAD antibody from Dr. W. H Oertel, Department of Neurology, University Hospital Großhadern, Munich, Germany; for the monoclonal GLU antibody from Dr. P. Strcit, IIirnforschungsinstitut, Zürich, Switzerland; and for additional TH-stained sections of n. raphe interpositus in marmoset from Dr. S. Hunt, MRC Molecular Neurology Unit, Cambridge. We thank Drs. F. Kolb, W. Fischer, and B. Cohen, who allowed us to process the brainstem tissuc of their experimental animals. We also thank $U$. Kappes for the excellent technical assistance. This work was supported by the Deutsche Forschungsgemeinschaft SFB 220/D8 and DI1, and "Neurovision." Bochum.

Correspondence should be addressed to Dr. A. K. E. Horn, Institute of Physiology, University of Munich, Pettenkoferstrasse 12, 80336 Munich, Germany. Copyright $\odot 1994$ Society for Neuroscience $0270-6474 / 94 / 142032-15 \$ 05.00 / 0$
Omnipause neurons (OPNs) are thought to act as a gating mechanism, or trigger, for the initiation of saccadic eye movements in all directions, as well as for quick phases of nystagmus (for revicw, see Fuchs et al., 1985). During fixation and slow cye movements the OPNs exert a tonic inhibition on horizontal saccadic burst neurons in the paramedian pontine reticular formation (PPRF) (Nakao et al., 1980; Furuya and Markham, 1982; Curthoys et al., 1984), and on the vertical saccadic burst neurons in the rostral interstitial nucleus of the medial longitudinal fascicle (riMLF) (Büttner-Ennever and Büttner, 1978; Nakao et al., 1988, 1989). This high level of tonic activity is interrupted $10-12 \mathrm{mscc}$ before a saccade, thereby releasing the inhibition from saccadic burst neurons. The disinhibition allows the burst neurons to activate the extraocular eye muscle motoneurons and results in a saccade. In current models the superior colliculus (sc) is thought to exert a strong control over the trigger for saccade generation. In addition to a monosynaptic excitatory input to OPNs (Raybourn and Keller, 1977; BüttnerEnnever et al., 1988) the sc must also activate an intermediate neuron population that in turn inhibits the OPNs for the initiation of a saccade. These intermediate inhibitory relay neurons are still the subject of controversy (Hepp et al., 1989).

In primates, OPNs lie within a cytoarchitecturally circumscribed nucleus on the midline in the caudal PPRF, which can be highlighted by cytochrome oxidase staining. It was named nucleus raphe interpositus (rip) by Büttner-Ennever et al. (1988). Furthermore, recording experiments in the monkey confirmed that virtually all neurons within the rip are OPNs (Langer and Kancko, 1990). Although the connectivity of the OPN region has been extensively studied with extra-and intracellular tracing methods in cats (King et al., 1980; Langer and Kaneko, 1983; Ohgaki et al., 1987; Strassman et al., 1987) and monkeys (for revicw, see Büttner-Ennever and Büttner, 1988; Ohgaki et al., 1989; Langer and Kaneko, 1990), the exact sources of inputs and synaptic mochanisms producing the characteristic firing pattern of OPNs are still not clear. Pharmacological experiments in cats suggest that the tonic activity of OPNs is controlled by inhibitory serotoninergic inputs, while the generation of the pause is produced by nonserotoninergic inputs (Baloh et al., 1982; Ashikawa et al,, 1991). The knowledge of the synaptic mechanism and circuits underlying saccade generation might help to explain the cause of certain saccadic disorders, such as opsoclonus or ocular flutter.

The aim of this study is an investigation of the transmitters that are associated with OPNs in the rip of the monkey. We applied immunocytochemistry, in situ hybridization, and specific uptake methods, along with immunocytochemistry for 
Table 1. Overview of the immunocytochemical methods with antisera dilutions and sources of the antisera used in the study

\begin{tabular}{|c|c|c|c|c|}
\hline Antiserum & Dilution & Source & Fixative & Method \\
\hline $\begin{array}{l}\text { PAV monoclonal } \\
\text { mouse }\end{array}$ & $1: 1000$ & Sigma & $\begin{array}{l}4 \% \mathrm{PFA} \\
1 \% \mathrm{PFA} / 2.5 \% \mathrm{GA}\end{array}$ & $\begin{array}{l}\text { thick }(25-40 \mu \mathrm{m}), \mathrm{ABC} \\
\text { fluorescence }\end{array}$ \\
\hline $\begin{array}{l}\text { 5-HT polyclonal } \\
\text { rabbit }\end{array}$ & $1: 8000$ & Incstar, Hamburg Germany & $4 \%$ PFA & thick $(40 \mu \mathrm{m}), \mathrm{ABC} ; \mathrm{PAP}$ \\
\hline $\begin{array}{l}\text { GAD polyclonal } \\
\text { sheep }\end{array}$ & $1: 2000$ & W. H. Oertel, Munich, Germany & $4 \%$ PFA & $\begin{array}{l}\text { thick }(40 \mu \mathrm{m}), \text { PAP, } \\
\text { double bridge }\end{array}$ \\
\hline $\begin{array}{l}\text { GABA polyclonal } \\
\text { rabbit }\end{array}$ & $\begin{array}{l}1: 4000 \\
1: 6000\end{array}$ & Incstar, Hamburg, Germany & $\begin{array}{l}1 \% \text { PFA } / 2.5 \% \text { GA } \\
2 \% \text { PFA } / 0.5 \% \text { GA }\end{array}$ & $\begin{array}{l}\text { thick }(40 \mu \mathrm{m}), \text { PAP } \\
\text { semithin, } \\
\text { postembedding, ABC }\end{array}$ \\
\hline $\begin{array}{l}\text { GLY polyclonal } \\
\text { rabbit }\end{array}$ & $1: 12,000$ & $\begin{array}{l}\text { SFRI Laboratoire, St-Jean-D'Illac, } \\
\text { France }\end{array}$ & $\begin{array}{l}1 \% \mathrm{PFA} / 2.5 \% \mathrm{GA} \\
5 \% \mathrm{GA}\end{array}$ & $\begin{array}{l}\text { thick }(40 \mu \mathrm{m}), \mathrm{ABC} \\
\text { semithin, } \\
\text { postembedding; } \mathrm{ABC}\end{array}$ \\
\hline $\begin{array}{l}\text { GLU monoclonal } \\
\text { mouse }\end{array}$ & $1: 12,000$ & P. Streit, Zürich, Switzerland & $1 \% \mathrm{PFA} / 2.5 \% \mathrm{GA}$ & $\begin{array}{l}\text { semithin, postembedding, } \\
\text { ABC }\end{array}$ \\
\hline $\begin{array}{l}\text { GLU polyclonal } \\
\text { rabbit }\end{array}$ & $1: 12,000$ & $\begin{array}{l}\text { SFRI Laboratoire, St-Jean-D'Illac, } \\
\text { France }\end{array}$ & $5 \% \mathrm{GA}$ & thick $(40 \mu \mathrm{m}), \mathrm{ABC}$ \\
\hline $\begin{array}{l}\text { TH polyclonal } \\
\text { rabbit }\end{array}$ & $1: 400$ & $\mathrm{ETI}, \mathrm{NJ}$ & $4 \%$ PFA & thick $(40 \mu \mathrm{m})$, PAP \\
\hline
\end{tabular}

parvalbumin (PAV), which was used here for the easy identification of OPNs in monkey, cat, and human.

\section{Materials and Methods}

\section{Transmitter immunocytochemistry}

Five macaque monkeys (Macaca mulatta and $M$. fascicularis) were killed with an overdose of Nembutal $(96 \mathrm{mg} / \mathrm{kg}$ ) and transcardially perfused with saline $\left(37^{\circ} \mathrm{C}\right.$ ) and one of the following fixatives (see Table 1): (1) 4\% paraformaldchyde (PFA) in $0.1 \mathrm{M}$ phosphate buffer (PB) (pH 7.4); (2) $5 \%$ glutaraldehyde (GA) in $0.1 \mathrm{M} \mathrm{PB}$; (3) $1 \% \mathrm{PFA} / 2.5 \% \mathrm{GA}$ in $0.1 \mathrm{M}$ PB. All brains were postfixed in the respective fixatives for a further $3-10 \mathrm{hr}$ at $4^{\circ} \mathrm{C}$ before being transferred to $0.1 \mathrm{M} \mathrm{PB}$ for vibratome cutting, or to increasing concentrations of sucrose for frozen sections. The brainstem was cut transversely in $40-\mu \mathrm{m}$-thick sections.

Free-floating sections of the region containing OPNs were immunocytochemically processed with antibodies directed against glutamate decarboxylase (GAD), tyrosine hydroxylase $(T H)$, serotonin $(5-H T)$, $\gamma$-aminobutyric acid (GABA), glycine (GLY), and glutamate (GLU). The sources and the appropriate dilutions of the primary antibodies are listed in Table 1. The monoclonal GLU antibody is characterized in Liu et al. (1989). Either the avidin-biotin or the peroxidase-antiperoxidase method was used to visualize the antibodies (Table 1).

GABA. GLY, and GLU immunocytochemistry of semithin sections. Two macaque brains $(0.5 \% \mathrm{PFA} / 2.5 \% \mathrm{GA})$ were used for the immunocytochemical detection of the amino acid transmitters GABA, GLY, and GLU in consecutive semithin sections with postembedding methods. Under the microscope the OPN area was dissected out from 100 $\mu \mathrm{m}$ vibratome sections and stored in $0.1 \mathrm{M} \mathrm{PB}$. As an aid to the identification of the OPN arca (see below), a set of alternate neighboring sections $(40 \mu \mathrm{m})$ were first processed for PAV immunocytochemistry. The dissected tissue was then postfixed in $1 \%$ osmium tetroxide $(2 \mathrm{hr})$ in $0.1 \mathrm{MPB}$, dehydrated in increasing concentrations of alcohols, and flat embedded in Epon resin at $60^{\circ} \mathrm{C}$ for $72 \mathrm{hr}$. From each block three sets of serial semithin $(0.5 \mu \mathrm{m}$ or $\mathbf{1} \mu \mathrm{m})$ sections were cut using glass knives, and mounted on gelatin-coated glass slides. The postembedding staining procedure was carried out according to the protocol of Liu et al. (1989). Briefly, the sections were etched with potassium methanolate ( $7 \mathrm{~min}$ ), followed by two washes in $100 \%$ methanol $(5 \mathrm{~min}$ ) and methanol $/ 0.1$ M potassium phosphate-buffered saline (KPBS) ( 5 min), and then treated with $1 \%$ sodium periodate $(7 \mathrm{~min})$ to remove the osmium. For the GABA and GLY immunoreaction two sets of sections were incubated in $0.1 \mathrm{M}$ sodium borohydride $(1 \mathrm{~min})$ and then washed in KPBS thoroughly. All slides were preincubated in $0.5 \%$ ovalbumin for $20 \mathrm{~min}$ and then incubated in the primary antibodies at the appropriate dilutions (Table 1) overnight at $4^{\circ} \mathrm{C}$. The location of the primary anti- bodies was detected either by the peroxidase-antiperoxidase or avidinbiotin method with a final reaction in $0.05 \%$ diaminobenzidine and $0.01 \%$ hydrogen peroxide for $1-10 \mathrm{~min}$. The diaminobenzidine end product was intensified by a subsequent treatment with silver ions. The incubation duration was controlled by monitoring the reaction of each slide under the microscope. After terminating the reaction in $1 \%$ acetic acid $(5 \mathrm{~min})$ the sections were washed in $2 \%$ sodium acetate and incubated in $0.05 \%$ gold chloride $(10 \mathrm{~min})$ and then rinsed in $2 \%$ sodium acetate before being fixed in $3 \%$ sodium thiosulfatc. As a control for specificity some neighboring sections were treated with GLY antiserum that had been preabsorbed with GA conjugates of $40 \mathrm{~mm}$ GLY with bovine serum albumin. Sections containing the superior olive with periolivary nuclei served as positive controls for the GLY antibody. All sections were examined and photographed under a light microscope (Nikon Biophot)

The transmitter inputs were quantified by counting the immunoreactive puncta, the assumed synaptic boutons, along the measured length of the contour of a rip neuron (putative $O P N$ ) using a graphic tablet (Minimop, Kontron). The TH-positive and 5-HT-positive inputs to rip neurons were analyzed in thick $(40 \mu \mathrm{m})$ sections that were counterstained with cresyl violet or thionin. Immunoreactive puncta or ax onal varicosities were considered to contact a rip neuron when its soma or dendrite and the attached varicosity were in the same focal plane and no space was seen between them. GABA-, GLY-, and GLU-immunopositive contacts were analyzed in semithin sections. In order to avoid multiple analysis of the same neuron, only two semithin sections $(1 \mu \mathrm{m})$ of every tissue block $(80-100 \mu \mathrm{m}$ section) were taken for counts of immunoreactive terminals at putative OPNs. All terminals were classified with regard to their location on OPN somata or proximal dendrites.

In addition, some semithin sections of the riMLF were immunoreacted for the visualization of GLY.

\section{Parvalbumin immunocytochemistry}

For the detection of parvalbumin (PAV) in the OPN region, brainstem sections of four macaque monkeys, two cats, and two normal humans were taken. The monkey and cat brains were fixed by transcardial perfusion (Table 1). The human brainstems were obtained $8 \mathrm{hr}$ postmortem: 2-cm-thick slices, containing the OPNs, were immersed in 4\% PFA in $0.1 \mathrm{M} \mathrm{PB}(\mathrm{pH} \mathrm{7.4)}$ for $20 \mathrm{hr}$ and then equilibrated in a mixture of the fixative and increasing concentrations $(10-30 \%)$ of sucrose $(15 \mathrm{hr})$ for freeze cutting. All brain tissue was cut at $40 \mu \mathrm{m}$ using a freezing microtome or vibratome. One series of free-floating sections was processed for the immunocytochemical detection of $\mathrm{PAV}$, and an alternate series of neighboring sections was reacted for 5-HT. Sections were pre- 


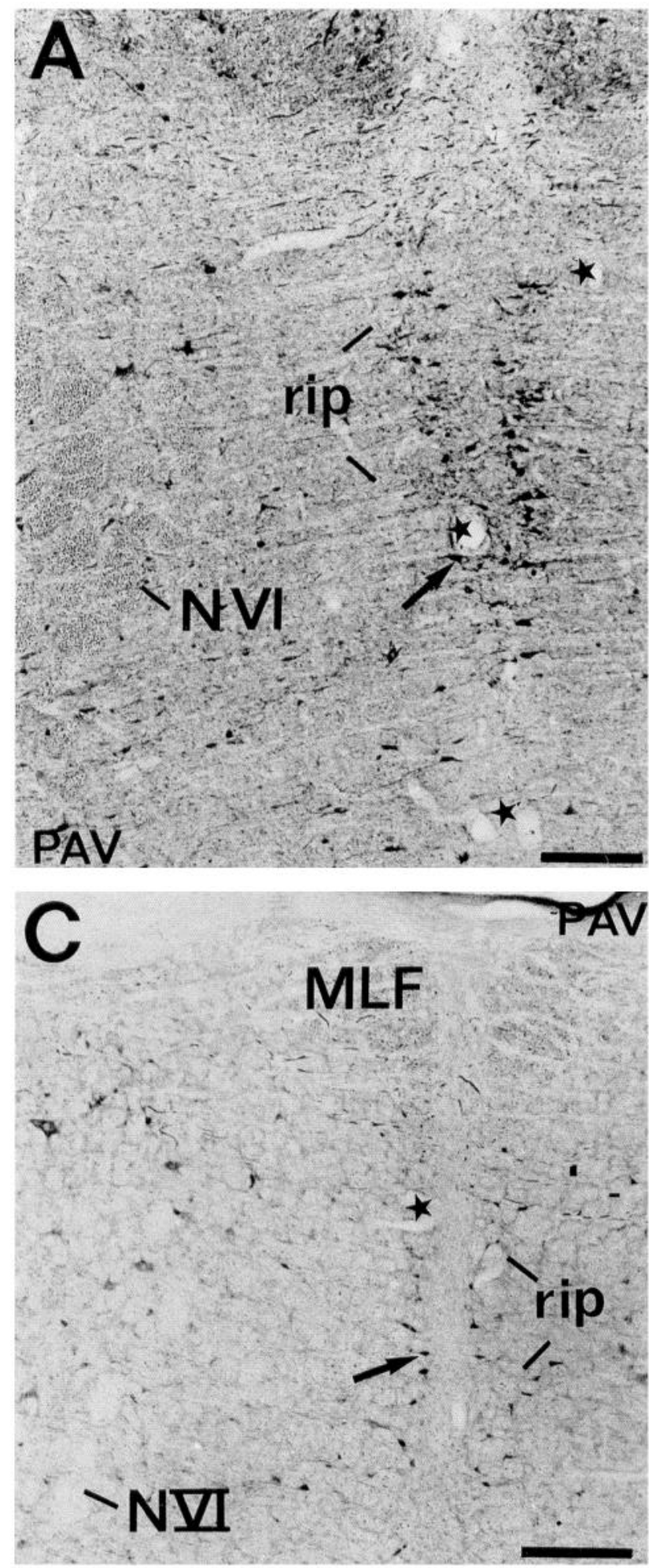

B $M L F$ rd

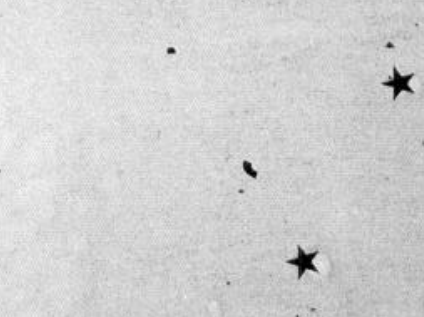

\section{'NVI}
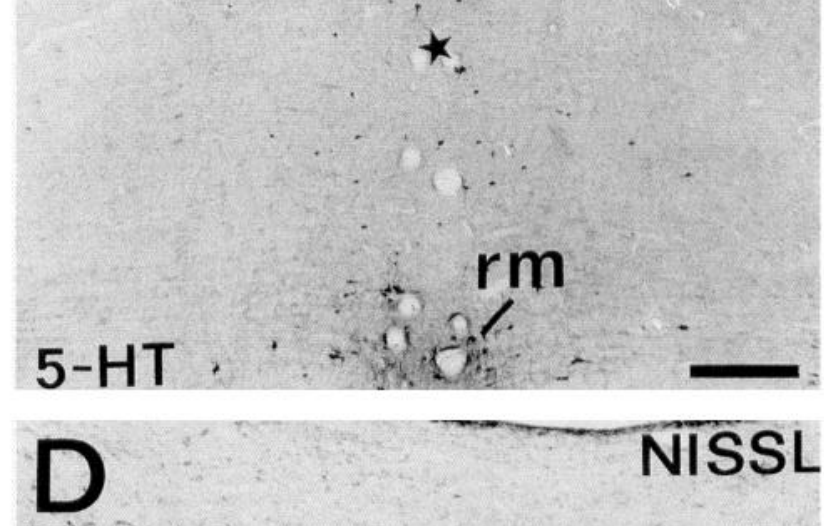

NISSL

\section{nrpc}
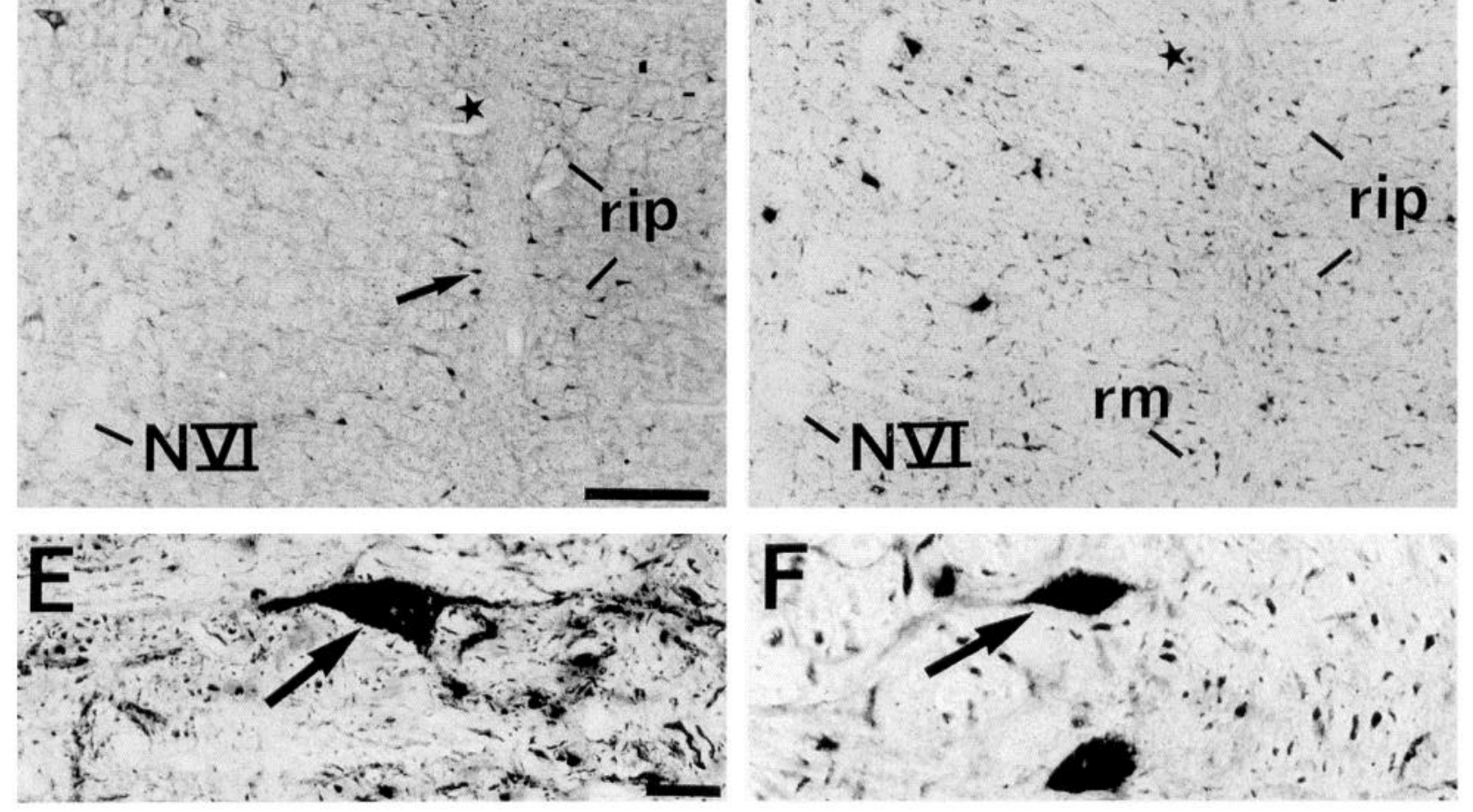
treated with $10 \%$ methanol $/ 3 \%$ hydrogen peroxide to suppress endogenous peroxidase activity and then preincubated in $0.1 \mathrm{M} P B$ containing $0.03 \%$ Triton X-100 with $1.5 \%$ normal horse serum for PAV, or $1.5 \%$ normal goat serum for $5-\mathrm{HT}$, for $1 \mathrm{hr}$. Sections were then treated either with a monoclonal PAV antibody or a polyclonal 5-HT antiserum overnight on a shaker at $4^{\circ} \mathrm{C}$ and processed using the avidin-biotin method (Table 1). For orientation a third set of sections was counterstained with cresyl violet. Cell measurements of the OPNs and calculations were performed with a graphic tablet (Minimop, Contron) and a personal computer.

\section{Uptake and retrograde transport of ${ }^{3} \mathrm{H}$-glycine}

One macaque monkey received a pressure injection of $1 \mu \mathrm{l}$ of ${ }^{3} \mathrm{H}-\mathrm{GLY}$ $(100 \mu \mathrm{Ci} / \mu l)$ into the riMLF on the right side. In the deeply anesthetized (Nembutal, $40 \mathrm{mg} / \mathrm{kg}$ body weight) animal we searched for the oculomotor/trochlear nucleus border with electrical stimulation $(3-10 \mathrm{~mA})$ using insulated tungsten electrodes (approximately $50 \mu \mathrm{m}$ tip length) until appropriate eye movements were observed. Using these coordinates the injection site was calculated according to the atlas of Shanta et al. (1968).

After a survival time of $17 \mathrm{hr}$ the animal was killed with an overdose of Nembutal $(80 \mathrm{mg} / \mathrm{kg}$ body weight) and transcardially perfused with $0.9 \%$ saline $\left(35^{\circ} \mathrm{C}\right)$ followed by $2 \% \mathrm{PFA} / 1 \% \mathrm{GA}$ in $0.1 \mathrm{M} \mathrm{PB}$. The brain was immersed in $10 \%$ sucrose in $0.1 \mathrm{M} \mathrm{PB}$ and transferred to $30 \%$ sucrose for $4 \mathrm{~d}$. The brainstem was cut at $40 \mu \mathrm{m}$ on a freezing microtome in the transverse plane. A series of equally spaced sections ( $200 \mu \mathrm{m}$ apart) and all OPN sections were mounted on gelatinized slides and then defatted, rehydrated, and dried in the oven for $48 \mathrm{hr}$ at $40^{\circ} \mathrm{C}$. In the darkroom, slides were dipped in Kodak NTB-3 nuclear track emulsion diluted 1:1 with distilled water and dried for $4 \mathrm{hr}$. After exposure for 5 weeks at $4^{\circ} \mathrm{C}$ the slides were developed in Kodak D-19 developer for 4 min at $12-15^{\circ} \mathrm{C}$ and fixed in Tetenal superfix (diluted $1: 9$ in distilled water) for $10 \mathrm{~min}$. After washing for $2 \mathrm{hr}$ in running water the sections were counterstained with cresyl violet, dehydrated, and coverslipped with Depex. Sections were examined and photographed under darkfield and bright-field illumination. The pattern of retrograde labeling was compared to that of a previous monkey, which had received a similar WGA-HRP injection $(0.4 \mu 1,2.5 \%)$ in to the riMLF.

\section{In situ hybridization for GAD $m R N A$}

In situ hybridization was performed to visualize the mRNA encoding the GABA-synthesizing enzyme GAD. One macaque monkey was killed with an overdose of Nembutal and transcardially perfused with $0.9 \%$ saline $\left(35^{\circ} \mathrm{C}\right)$, followed by cold $4 \%$ PFA in $0.1 \mathrm{M} \mathrm{PB}, \mathrm{pH} 7.4$. The following procedures were carried out under sterile conditions. The brain was removed from the skull. A 6-mm-thick slice containing the OPNs was dissected, freed of the dura and pia mater, and transferred through several changes of the fixative, before being placed into $20 \%$ RNasefree sucrose in autoclaved $0.1 \mathrm{M} \mathrm{PB}$ for one night. Hybridization and staining procedures were carried out as described (Wahle and Beckh, 1992). Briefly, transverse sections $(20-25 \mu \mathrm{m})$ were cut using a cryostat (Leica) and collected in $2 \times \mathrm{SSC}(0.3 \mathrm{M} \mathrm{NaCl}$ and $0.03 \mathrm{M}$ sodium citrate). After a short incubation in a mixture of $2 \times \mathrm{SSC}$ and prehybridization solution $(1: 1)$, the sections were transferred to prehybridization solution into a glass plate with 30 wells, covered with a glass lid, and incubated for $2-3 \mathrm{hr}$ at $45^{\circ} \mathrm{C}$. Sections were then hybridized with an antisense digoxigenin-UTP (Dig-UTP)-labeled GAD-cRNA probe that was transcribed in vitro using the 2.3 kilobase feline $\mathrm{GAD}_{67} \mathrm{cDNA}$ cloned in pSP65 (Kaufman et al., 1986) as template. The probe was diluted 1:100500 . Hybridization proceeded for $9-16 \mathrm{hr}$ at $45^{\circ} \mathrm{C}$. The immunocyto- chemical detection of the hybridized probes was carried out under nonsterile conditions. Sections were washed in $2 \times \mathrm{SSC}, 2 \times \mathrm{SSC} / 50 \%$ formamide, $0.1 \times \mathrm{SSC} / 50 \%$ formamide, and $0.1 \times \mathrm{SSC}(15 \mathrm{~min}$ each) at $45^{\circ} \mathrm{C}$, followed by several changes of $0.1 \mathrm{M}$ Tris-buffered saline (TBS) $(\mathrm{pH} 7.6)$ at room temperature. Sections were incubated in a blocking solution (block reagent, Boehringer Mannheim) for $1 \mathrm{hr}$ and then in sheep anti-Dig antibody $F(a b)_{2}$ fragments labeled with alkaline phosphatase (Boehringer Mannheim) diluted at 1:1500 for $3 \mathrm{hr}$ at room temperature. After three $15 \mathrm{~min}$ rinses in TBS, sections were equilibrated in $0.1 \mathrm{M}$ TBS-Mg buffer (TBS with $0.05 \mathrm{M} \mathrm{MgCl}_{2}, \mathrm{pH}$ 9-9.5). The antibody-alkaline phosphatase conjugate was visualized by incubation of the sections in nitroblue tetrazolium (Sigma; $0.35 \mathrm{mg} / \mathrm{ml}$ ) and 5-bromo-4-chloro-3-indolyl-phosphate (Sigma; $0.18 \mathrm{mg} / \mathrm{ml}$ ) in TBS$\mathrm{Mg}$ buffer ( $\mathrm{pH} 9-9.5$ ) in the dark. The development of the purple reaction product was controlled by visual inspection under the microscope. Although positive staining was seen in the superior colliculus after $6 \mathrm{hr}$, the reaction time was prolonged up to $24 \mathrm{hr}$. The reaction was stopped by several rinses in TBS ( $\mathrm{pH} 7.5)$. The sections were mounted and coverslipped in Eukitt for analysis and microphotography.

Controls. Hybridization with a sense probe diluted 1:100-500 revealed no signals in monkey brainstem. As positive control the antisense probe was tested on rat and cat cortex sections, where it revealed the typical populations of interneurons (Wahle and Beckh, 1992). Omitting the anti-Dig antibody or incubating sections with the alkaline phosphatase substrate only did not reveal any staining at all.

Double labeling. To combine GAD in situ hybridization and PAV immunocytochemistry, hybridizcd scctions werc stopped by rinses in TBS and blocked with $1 \%$ bovine serum albumin in TBS for $1 \mathrm{hr}$. The free-floating sections were then incubated in PAV antibody diluted 1:2000 for $16 \mathrm{hr}$. After three $15 \mathrm{~min}$ rinses in TBS sections were incubated in FITC-conjugated rabbit anti-mouse (Dakopatts, Hamburg, Germany) at 1:80 for $3 \mathrm{hr}$ at room temperature, rinsed, mounted on gelatinized slides, and coverslipped wet with TBS-glycerol $(1: 1)$. Sections were analyzed with a Zeiss axiophot and photographed on T-Max 400 film.

\section{Results}

\section{PAV immunolabeling of rip}

Macaque monkey. At the pontine-medullary junction of the monkey brainstem, the vestibular nuclei, the abducens nucleus (VI), and the superior olive exhibited a high level of cellular and neuropil labeling for PAV, whereas the paramedian reticular formation contained fewer immunoreactive neurons and less neuropil labeling. However, ventral to VI at the midline, confined to the levels at which the abducens nerve (NVI) rootlets pass through the brainstem, a compact cell group stood out in PAV-immunostained material (Fig. 1 $A$ ). These PAV-immunoreactive cells were multipolar, medium sized $\left[\left(D_{\min }+D_{\max }\right) / 2\right.$ $=35.99 \mu \mathrm{m} ; \mathrm{SD}=6.51 \mu \mathrm{m} ; N=86]$, and arranged in a band of two vertical cell columns adjacent to the midline, with their horizontally oriented dendrites reaching across the midline (Fig. $1 E$ ). The location and appearance of this cell group were identical with the description of the rip in the monkey (BüttnerEnnever et al., 1988). In contrast, only weak PAV immunoreactivity of a few cells with additional neuropil labeling was seen in the nucleus raphe pontis (rp) dorsal and rostral to rip. The nucleus raphe magnus ( $\mathrm{rm})$, ventral to rip, was devoid of

Figure 1. Photomicrographs of frontal sections through the OPN area of the monkey $(A, B)$ and cat $(C, D)$. $A$ and $B$ are neighboring sections of the monkey immunoreacted for PAV $(A)$ and 5-HT $(B)$. A, The OPNs in the rip, arranged in two cell columns at the midline between the rootlets of the NVI, stand out by their PAV immunolabeling. The adjoining raphe nuclei, rd and rm, are PAV negative, and the adjacent paramedian reticular formation contains only a few PAV-positive cells with prominent neuropil labeling. $B$, Within the raphe nuclei the rd and rm contain 5-HT-positive cells, whereas the rip neurons (OPNs) are not 5-HT immunoreactive. $C^{\prime}$ and $D$ are photomicrographs of neighboring sections of the cat, immunoreacted for PAV $(C)$ and stained with cresyl violet $(D)$. C, Between the NVI rootlets the PAV-immunopositive OPNs can be seen clustered around the midline beneath the MLF. $D$, In the Nissl-stained neighboring section the rip can be delineated from rm ventrally, with the aid of the PAV comparison, but not as clearly as in monkey (see Fig. $8 B$ ). $E$ and $F$, High-power magnification of PAV-immunoreactive OPNs in the monkey $(E$; from $A$, arrow) and cat $(F$; from $C$, arrow), demonstrating the characteristic shape of the neurons with their horizontally oriented dendrites reaching to the midline. Cat OPNs are smaller than those of monkey. For orientation blood vessels are indicated by stars. See Appendix for list of abbreviations. Scale bars: $A-D, 0.5 \mathrm{~mm} ; E$ and $F, 30 \mu \mathrm{m}$. 

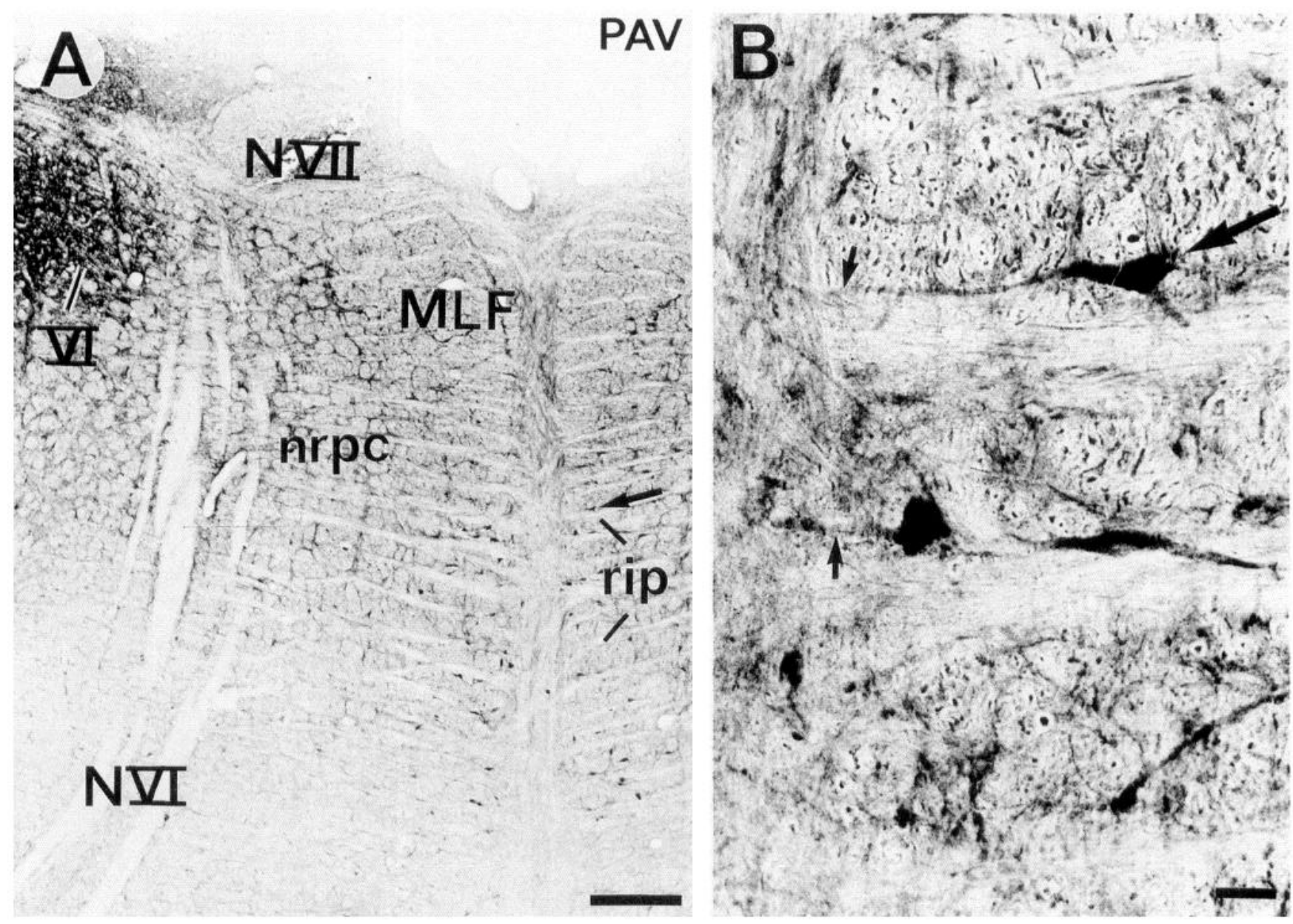

Figure 2. A, Photomicrograph of a frontal section through the OPN area in human immunostained for PAV. PAV-immunoreactive putative OPNs in rip are located beneath the MLF between the NVI rootlets, confined to the medial part of the nrpc. $B$, High-power magnification from $A$ (arrow) showing three somata (upper two-thirds) and three cut dendrites (lower third) of PAV-immunoreactive neurons in rip, with the characteristic features of OPNs. Note the horizontally oriented dendrites reaching across the midline (small arrows) on the left. Scale bars: $A, 0.5 \mathrm{~mm} ; B, 30 \mu \mathrm{m}$.

PAV-immunoreactive neurons (Fig. $1 \mathrm{~A}$ ). Although the rip is bordered by 5 -HT-positive neurons in the nucleus raphe dorsalis (rd) dorsally and in the rm ventrally (see also Pecci Saavedra et al., 1983), rip neurons themselves do not display any 5-HT immunoreactivity (Fig. $1 B$ ).

Cat. In the cat, unlike in the monkey, it has not been possible to identify the OPNs by their cytoarchitectural appearance in Nissl sections alone. After immunocytochemical staining with PAV antiserum, a distinct group of labeled neurons was found near the midline within the caudal pontine reticular formation between the rootlets of the VIth nerve. As in the monkey, the appearance of this PAV-immunoreactive cell group was confined to levels at which the VIth nerve passes ventrally through the brainstem. It was located between 1.8 and $2.8 \mathrm{~mm}$ beneath the floor of the fourth ventricle and extended about $1.5 \mathrm{~mm}$ in the anterior-posterior direction (Fig. 1C). These PAV-immunoreactive neurons were medium sized $\left[\left(D_{\min }+D_{\max }\right) / 2=30.78\right.$ $\left.\mu \mathrm{m}, \mathrm{SD}=5.59 \mu \mathrm{m} ; N=41 ; D_{\max }=41.18 \mu \mathrm{m}, \mathrm{SD}=9.51 \mu \mathrm{m}\right]$, with their long axis oriented horizontally (Fig. $1 F$ ). They were arranged in a less orderly manner, compared to those in the monkey, but were clustered around the midline, embedded in the descending fibers of the predorsal bundle forming a homolog to rip. Comparison with either Nissl-stained (Fig. $1 C, D$ ) or 5-HTimmunoreacted neighboring sections showed that these PAV- immunoreactive neurons formed a distinct group that differed from the adjacent raphe nuclei (Taber et al., 1960). The dorsorostral rp consists of a bilateral group of small neurons, some of which are 5-HT positive. PAV immunocytochemistry of the rp revealed a dense neuropil labeling with a few weak PAVpositive cells intermingled. As in the monkey, the neurons of rip displayed a distinct dark PAV immunolabeling that was confined exclusively to the cell bodies and proximal dendrites (Fig. $1 F$ ). The ventral $\mathrm{rm}$, which consisted of a more densely packed cell group with some 5-HT-positive neurons, was devoid of any PAV immunolabeling.

Human. At the location corresponding to that in monkey and cat, PAV immunocytochemistry revealed a group of horizontally oriented medium-sized neurons $\left[\left(D_{\min }+D_{\max }\right) / 2=33.55\right.$ $\mu \mathrm{m} ; \mathrm{SD}=5.27 \mu \mathrm{m} ; N=134]$ adjacent to the midline, that we consider as the homolog rip (Büttner-Ennever et al., 1988). These PAV-immunoreactive neurons lay scattered within $1 \mathrm{~mm}$ of the midline, and extended $2.6 \mathrm{~mm}$ in the anterior-posterior direction. The rip differed from the lateral and rostral adjoining nucleus reticularis pontis caudalis (nrpc) by its distinctly labeled elongated cells and poor neuropil-PAV immunolabeling. The nrpc contained only a few scattered PAV-immunoreactive neurons, with irregularly oriented axes of diverse forms, small, large, round, or fusiform PAV-immunoreactive neurons (Fig. $2 A, B$ ). 


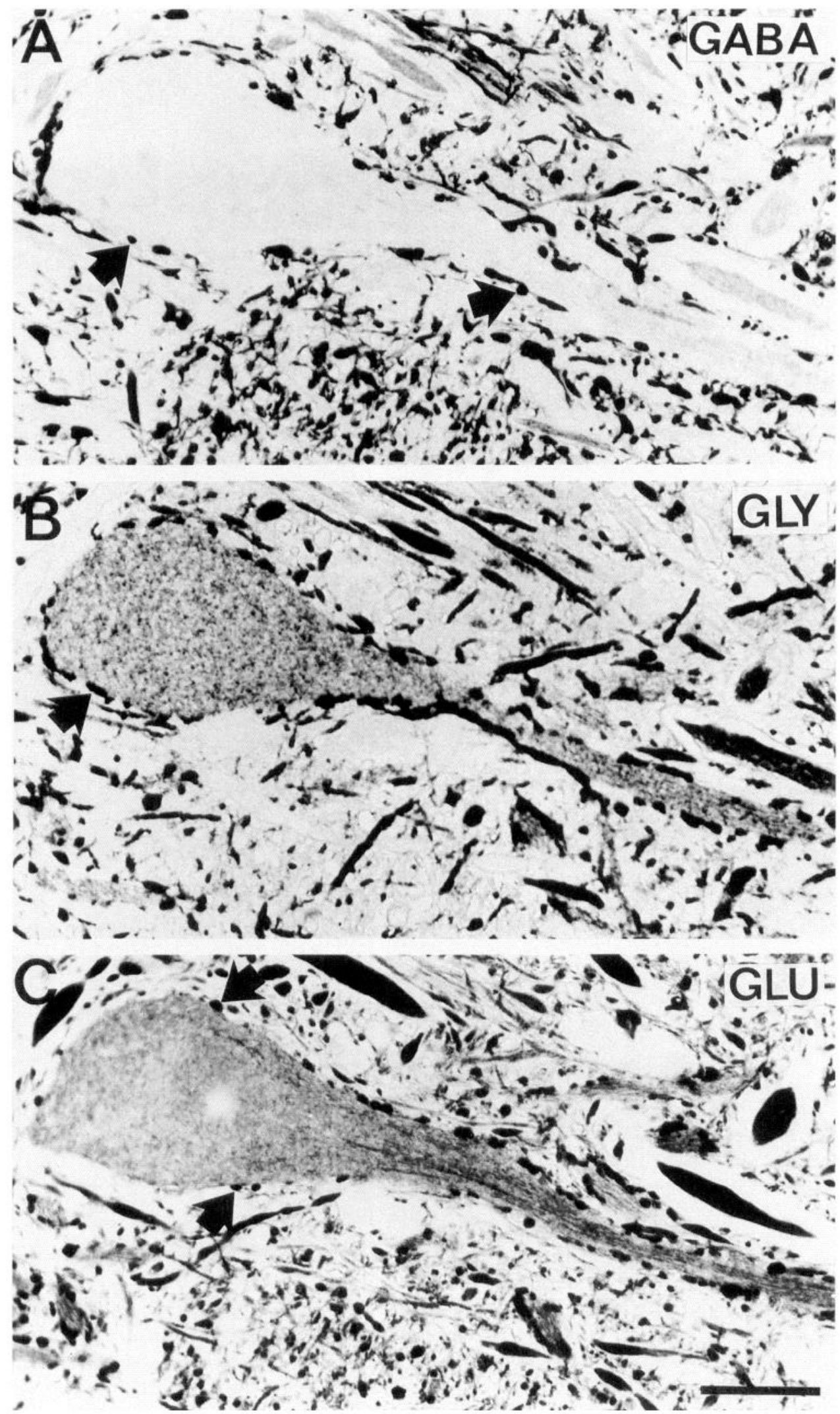

Figure 3. High-power photographs of consecutive semithin sections of a putative OPN in the monkey immunoreacted with GABA $(A)$, GLY $(B)$, and GLU antiserum $(C)$. For reasons given in the Discussion, only the GLY immunolabeling is considered functionally significant. The putative OPN is GABA negative $(A)$, but displays GLY and GLU immunoreactivity $(B, C)$. The somata and dendrites of the neuron are contacted by numerous GABA- and GLY-positive puncta $(A, B$, arrows), whereas only a few GLU-positive terminals are associated with the soma (arrows) and mainly confined to the dendrite $(C)$. Scale bar, $20 \mu \mathrm{m}$.
Transmitters of rip neurons (putative OPNS)

Immunolabeling of rip. Examination of immunocytochemically treated thick $(40 \mu \mathrm{m})$ sections did not reveal any positive la- beling of cell bodies in rip for the transmitter-related substances TH, 5-HT (see above; Fig. 1B), GAD, or GABA, but displayed a moderate GLU and GLY immunoreactivity (Fig. 3). The immunocytochemical detection of GLY was critically dependent 

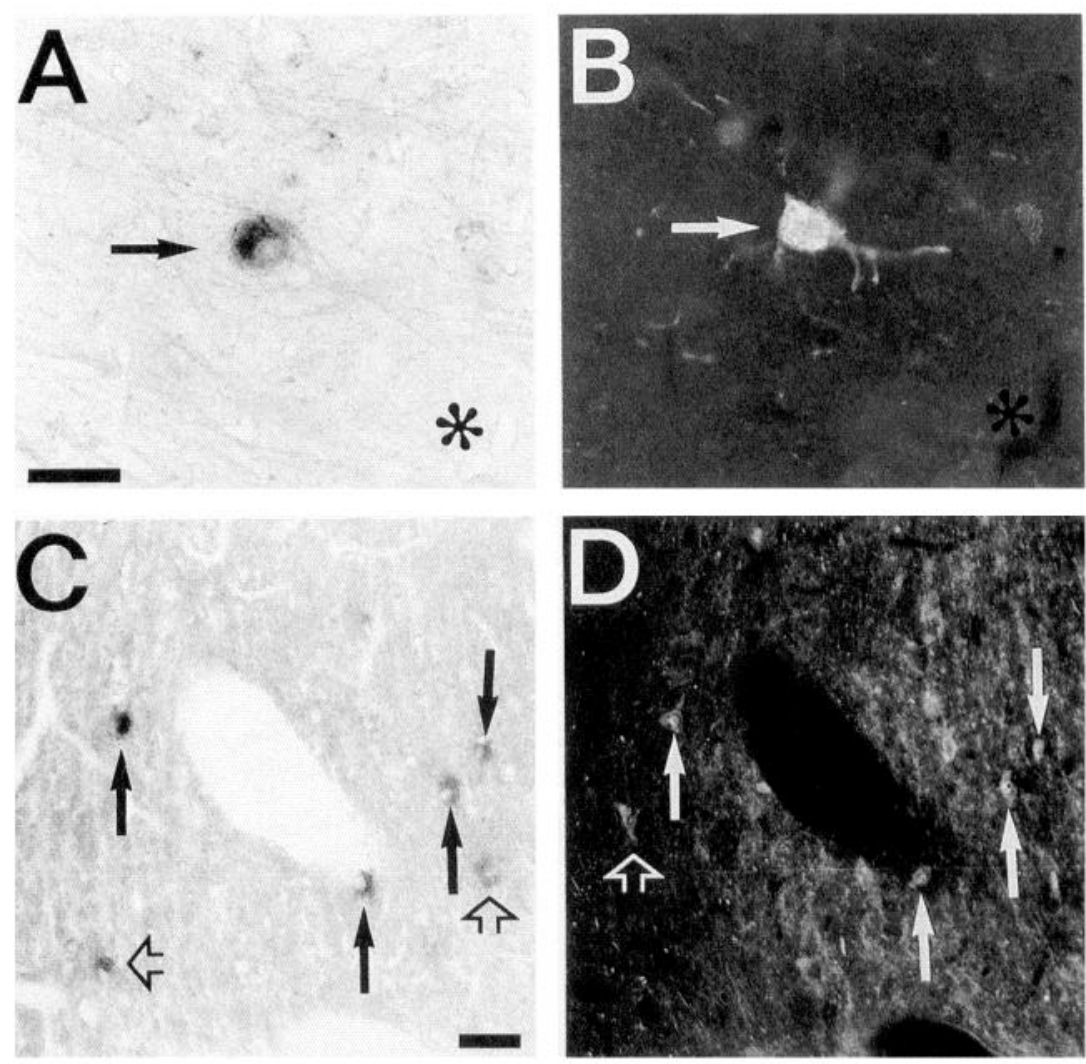

Figure 4. Photomicrographs of frontal sections through the monkey brainstem that has undergone in situ hybridization for GAD mRNA, followed by PAV immunoreaction. $A$ and $B$ are highpower photomicrographs of a doublelabeled neuron in the lateral reticular formation expressing GAD mRNA $(A)$ and PAV immunofluorescence shown by a dark-field photograph $(B)$. $C$ and $D$ are photographs of a frontal section showing neurons in the pretectum that express both GAD mRNA $(C$, solid arrows) and PAV immunofluorescence $(D$, solid arrows). Some neurons express only GAD mRNA $(C$, open arrows) or only PAV immunoreactivity $(D$, open arrow, $F) . E$ and $F$ are photographs of a frontal section through the OPN area (rip) demonstrating that OPNs display only strong PAV immunofluorescence $(F)$, but lack any GAD mRNA expression $(E)$. Asterisks indicate the same blood vessels in light- and dark-field photographs. Scale bars: $A$ and $B, 50$ $\mu \mathrm{m} ; C-F, 100 \mu \mathrm{m}$.
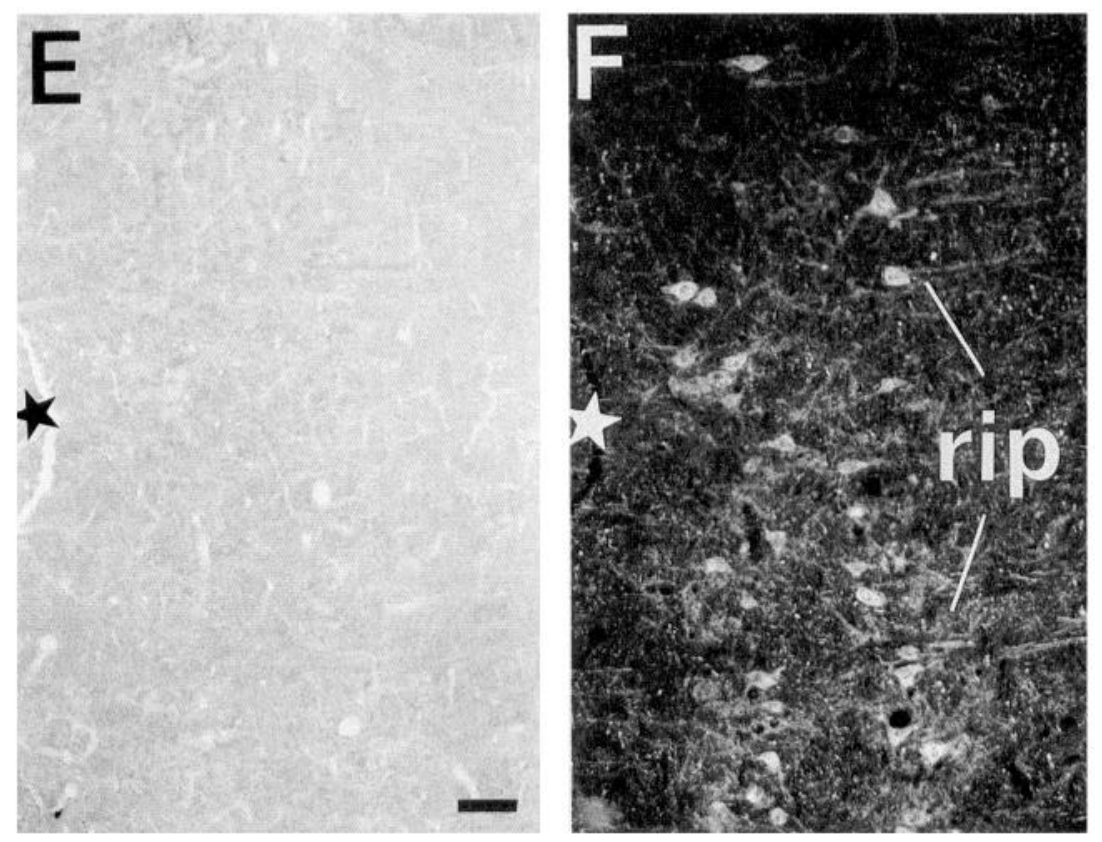

on the pretreatment with sodium borohydride to reduce remaining aldehyde groups and double bonds created by GAprotein cross-linking (Kosaka et al., 1986), and the use of the correct high dilution $(1: 12,000)$ of the GLY antibody. Preliminary immunocytochemical preparations employing lower dilutions (e.g., 1:4000) of the primary antibody, as successfully used in a previous study (Vater et al., 1990), did not reveal any cell body labeling, but only terminal staining. This was possibly due to the steric hindrance of the primary antibody known as the "Bigbee effect" (Bigbee et al., 1977). In our material we used the strong immunoreactivity of known glycinergic neurons in the medial nucleus of the trapezoid body (MNTB) (Vater et al., 1990), located in the same sections, as a positive control. Only sections with specific GLY immunoreactivity in MNTB cell bodies were evaluated. The moderate GLY immunolabeling of the rip neurons was partly obscured by dense punctate labeling outlining the somata and proximal dendrites.

The postembedding immunocytochemical staining of Epon- 


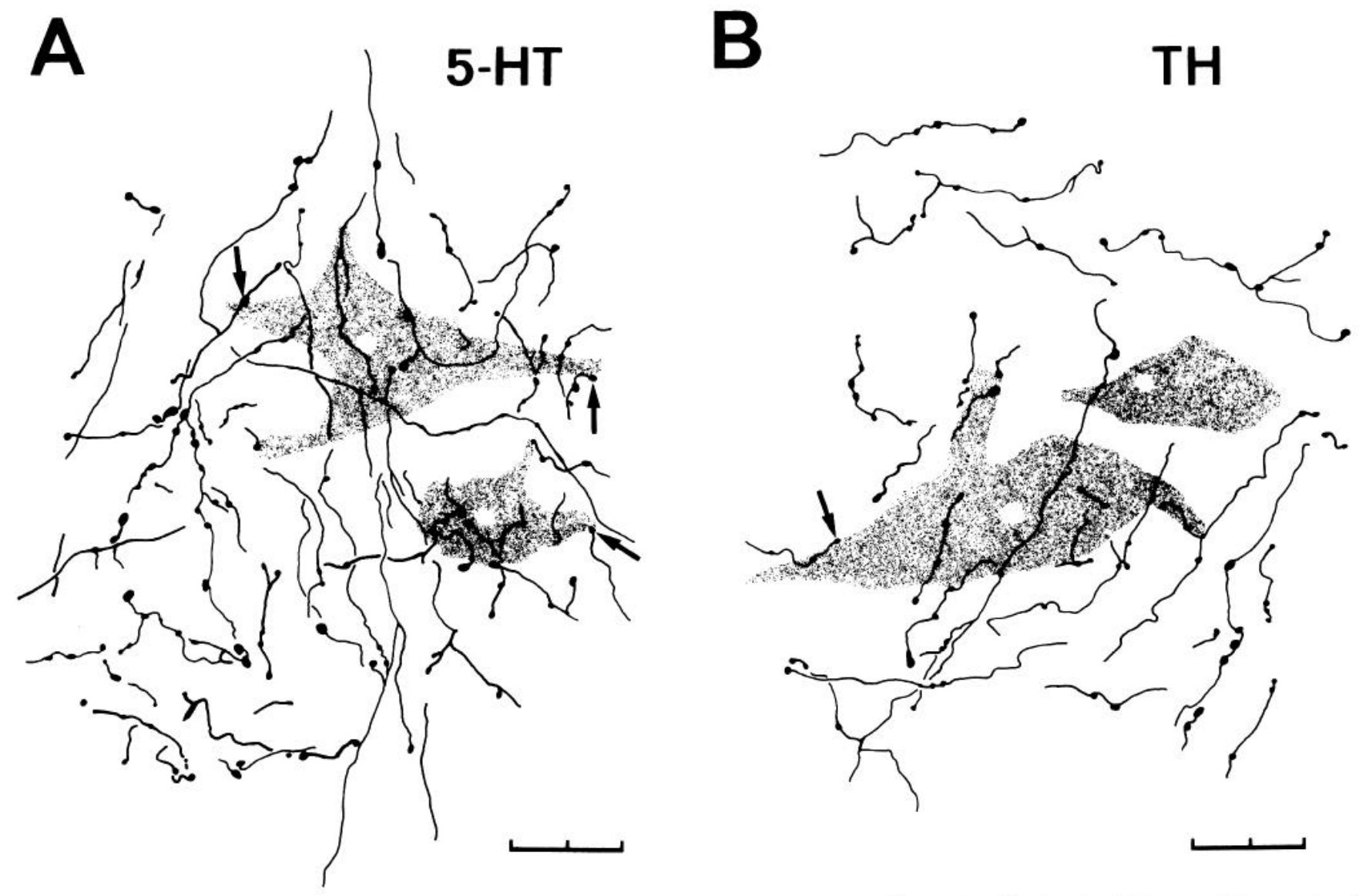

Figure 5. Reconstruction of 5-HT-immunopositive $(A)$ and catecholamine TH-immunopositive $(B)$ profiles in the OPN area of the monkey from $40 \mu \mathrm{m}$ cresyl violet-stained sections at high-power magnification. OPNs (shaded cells) are embedded in a network of 5-HT-positive and THpositive fibers, but only few varicosities (arrows) are in close contact with the OPN somata. Scale bar, $20 \mu \mathrm{m}$.

embedded material enabled us to study the amino acid transmitter content of consecutive semithin sections of single rip neurons, putative OPNs. Figure 3 demonstrates that the somata of the rip neurons did not show any GABA immunoreactivity (Fig. $3 A$ ), but they do have a moderate GLY and GLU immunoreactivity, confirming the results obtained in thick sections (Fig. 3B,C). The intensity of the GLY labeling was clearly above background, similar to that of saccadic inhibitory burst neurons (IBNs) and neurons of the ventral nucleus of the trapezoid body (VNTB), but much weaker than the strongly labeled neurons in the MNTB. In the semithin sections the GLY immunoreactivity was exclusively confined to the somata of rip neurons, whereas virtually all cells displayed various degrees of GLU immunoreactivity.

In situ hybridization. The distribution in the monkey brainstem of neurons at the level of the OPNs that express mRNA, encoding the $\mathrm{GAD}_{67}$ isoform, basically resembled that of $\mathrm{GAD} /$ GABA-immunoreactive neurons (A. K. E. Horn, unpublished observations). Intensely, and less intensely, labeled cells of different soma sizes were found in the superior and inferior colliculi, scattered beneath the medial longitudinal fascicle (MLF), in the periolivary nuclei, the periaqueductal gray, and rm. Only in the latter two areas did we observe more mRNA-expressingthan GAD- or GABA-immunoreactive cells. More anteriorly, many GAD mRNA-expressing neurons occurred in the pretectal areas, and the nucleus of the optic tract (NOT). Even the highly myelinated NOT contained many intensely labeled large cells in addition to weaker labeled smaller somata (Fig. $4 C$ ). However, the area containing the OPNs was devoid of GAD mRNA-expressing neurons (Fig. $4 E$ ). This observation was confirmed by marking the rip neurons by their strong PAV

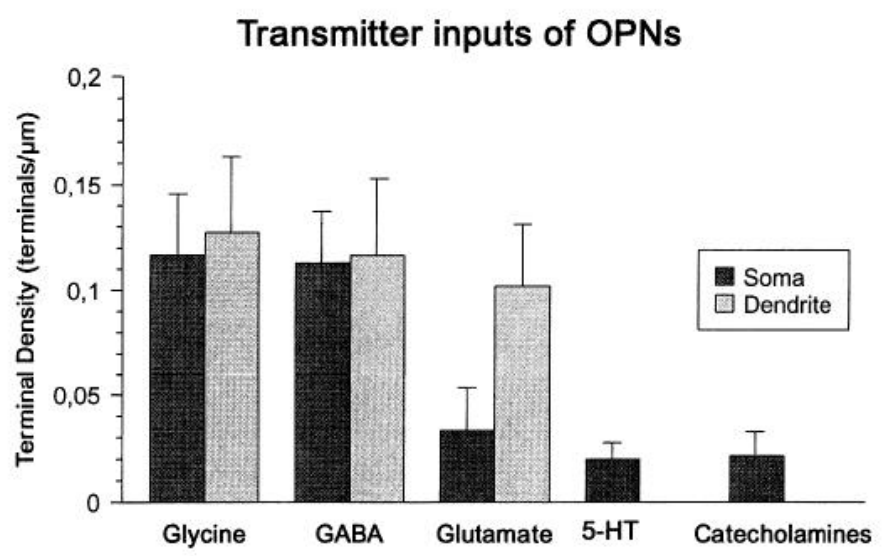

Figure 6. Histogram with SDs demonstrating the quantitative comparison of the analyzed transmitter inputs to putative OPNs: OPNs are contacted by comparably high numbers of GLY- and GABA-immunoreactive terminals along the somata (dark bars) and dendrites (light bars). GLU-positive terminals are mainly confined to the dendrites, whereas only a few GLU-, 5-HT-, and TH-positive terminals contact OPN somata. The analysis was performed on 111 rip neurons (putative OPNs) (GLY), $99 \mathrm{GABA}$, and $80 \mathrm{GLU}$ in semithin sections, and 79 5 -HT and $30 \mathrm{TH}$ rip neurons in $40 \mu \mathrm{m}$ sections. 
Table 2. Comparison of the retrograde labeling in two cases: one with a WGA-HRP injection into the riMLF, the other with a ${ }^{3} \mathrm{H}$ GLY

\begin{tabular}{|c|c|c|c|c|}
\hline & \multicolumn{2}{|c|}{$\begin{array}{l}\text { WGA-HRP-labeled } \\
\text { cells }\end{array}$} & \multicolumn{2}{|c|}{$\begin{array}{l}{ }^{3} \mathrm{H}-\mathrm{GLY} \text {-labeled } \\
\text { cells }\end{array}$} \\
\hline & $\begin{array}{l}\text { Ipsi- } \\
\text { lateral }\end{array}$ & $\begin{array}{l}\text { Contra- } \\
\text { lateral }\end{array}$ & $\begin{array}{l}\text { Ipsi- } \\
\text { lateral }\end{array}$ & $\begin{array}{l}\text { Contra- } \\
\text { lateral }\end{array}$ \\
\hline $\mathrm{mv}$ & ++ & ++ & & \\
\hline sv & + & & + & \\
\hline sg & + & & & \\
\hline Lateral nrpo & ++ & + & & + \\
\hline rip & + & ++ & + & ++ \\
\hline $\mathrm{rp}$ & ++ & & & \\
\hline medrf & + & + & + & \\
\hline Beneath BC & + & ++ & & \\
\hline sc & ++ & + & & \\
\hline $\mathrm{nPC}$ & & + & & \\
\hline iC & & ++ & & \\
\hline riMLF & & ++ & & \\
\hline
\end{tabular}

+ indicates weak retrograde labeling; ++ , strong retrograde labeling. WGA-HRP labels all afferents, whereas specific uptake of GLY labels only glycinergic cell groups-rip in particular. Note that there are no labeled cells in the sc after ${ }^{3} \mathrm{H}$ GLY injection. See Appendix for abbreviations.

immunoreactivity in in situ hybridized, labeled sections (Fig. $4 E, F)$. Double-labeled neurons, expressing GAD mRNA and PAV immunofluorescence, were observed in several areas, for example, ventral to the brachium conjunctivum $(\mathrm{BC})$ and pretectum (Fig. $4 A-D$ ). Interestingly, only subsets of neurons were double labeled; other cells expressed either GAD mRNA or PAV immunoreactivity alone (Fig. $4 C, D$ ).

$G L Y$ immunolabeling of the riMLF. The riMLF was highlighted by its relatively dense supply of GLY-immunoreactive fibers and puncta, whereas a much lower concentration of immunolabeled puncta was observed in the surrounding areas. A considerable number of GLY-immunostained puncta was exclusively associated with large multipolar neurons, outlining their somata and proximal dendrites (see Fig. $8 C$ ). No GLYimmunoreactive neurons were detected within the riMLF.

\section{Transmitter inputs to rip neurons}

Although the cells of rip are embedded in a dense network of 5-HT-immunoreactive and TH-immunoreactive fiber tracts, only a few varicosities of 5-HT-positive and TH-positive fibers were in close contact with Nissl-stained cell bodies of putative OPNs. This is demonstrated in Figure 5, $A$ and $B$, in a drawing of all varicosities seen on focusing through the full thickness of the section. In contrast to the sparse number of monoaminergic contacts, the somata and proximal dendrites of the rip neurons received a dense supply of GLY- and GABA-/GAD-immunoreactive puncta (Fig. $3 A, B$ ). The quantitative analysis for amino acid transmitter inputs was performed on semithin sections, and that for the monoaminergic inputs on thick sections $(40 \mu \mathrm{m})$. The histogram in Figure 6 compares the terminal counts, quantitatively. Similarly high numbers of GABA- and GLYimmunoreactive terminals contact the somata and dendrites of rip neurons as well. In contrast, GLU-immunoreactive terminals were almost entirely restricted to the dendrites of rip neurons (Figs. $3 C, 6$ ). As judged by their localization on high-power photomicrographs of consecutive semithin sections, some puncta might colocalize GABA and GLY immunoreactivity, but the
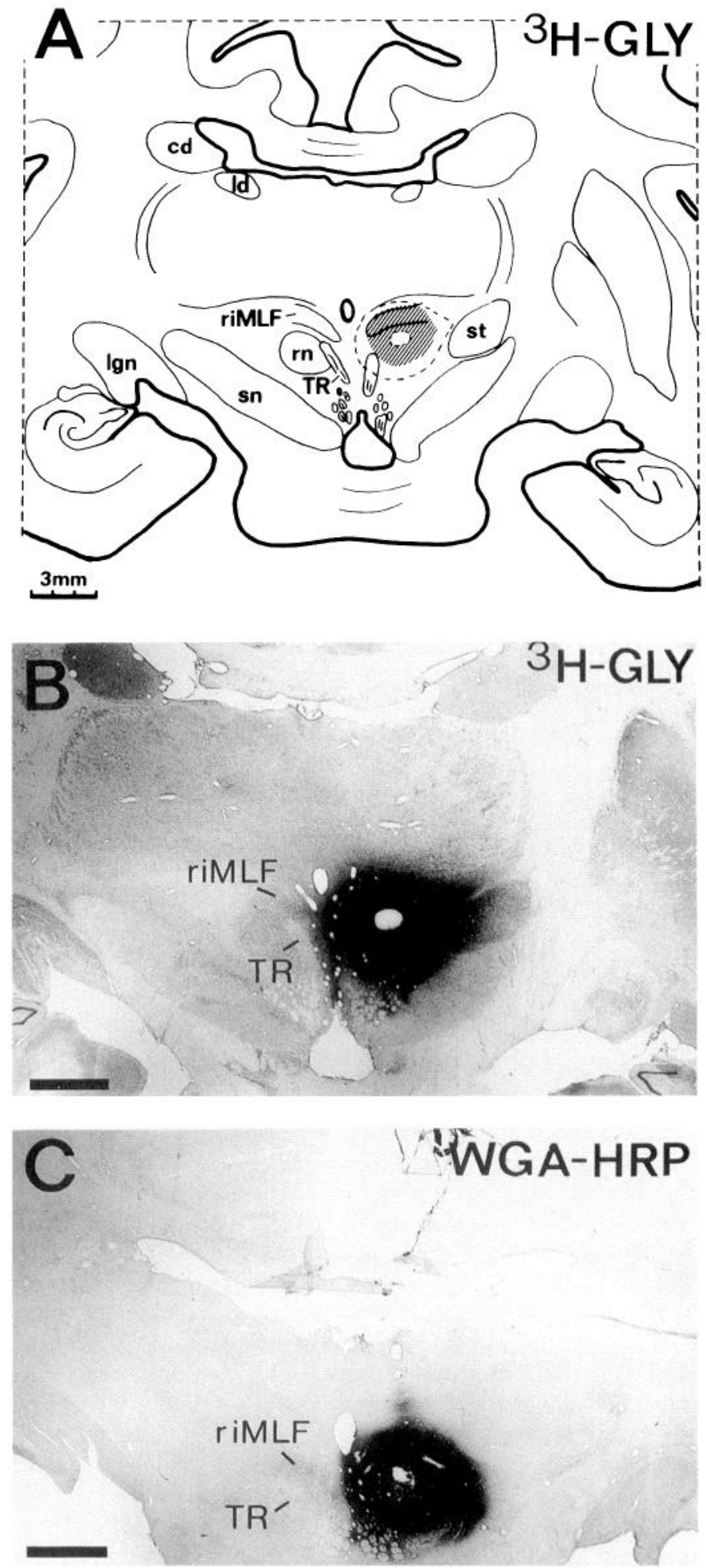

Figure 7. Reconstruction $(A)$ and photomicrographs of the injection site with ${ }^{3} \mathrm{H}-\mathrm{GLY}(B)$ and with WGA-HRP $(C)$ in the caudal riMLF. $A$, Drawing of the section in $B$ : the shaded area indicates the estimated ${ }^{3} \mathrm{H}-\mathrm{GLY}$ uptake area; the broken line outlines the region of spread. Both injection sites are comparably placed involving the whole riMLF, the underlying mesencephalic reticular formation, and $\mathrm{rn}$. See Appendix for list of abbreviations. Scale bars, $3 \mathrm{~mm}$. 

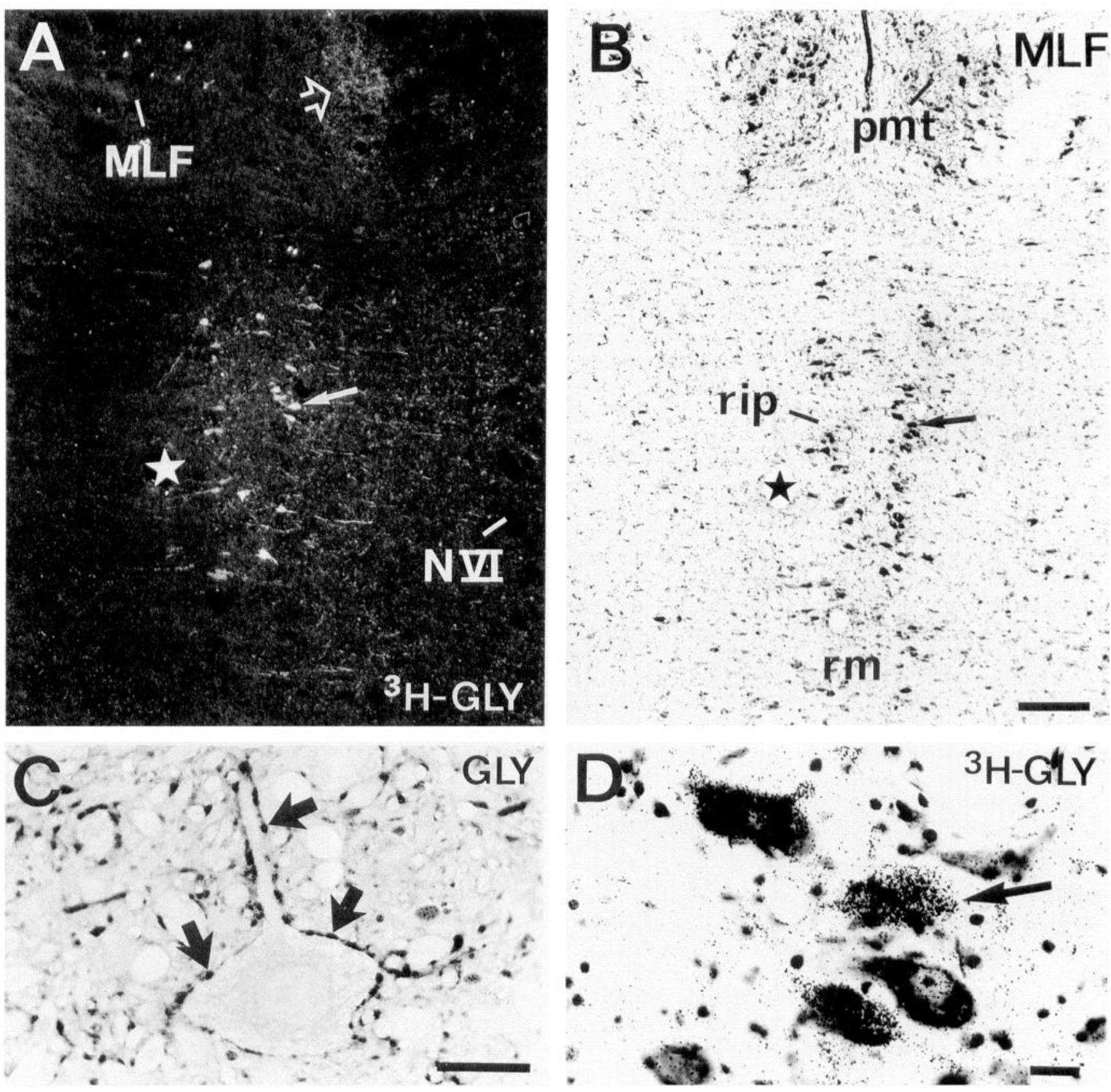

Figure 8. Dark-field $(A)$ and light-field $(B)$ microphotographs of a frontal section through the OPN region showing the retrograde labeling in rip following a ${ }^{3} \mathrm{H}-\mathrm{GLY}$ injection into the riMLF (Fig. 7). Dense silver grain accumulations were selectively found overlying neurons in the rip ( $A$, $B$ ); nonspecifically labeled afferents are seen over pmt (open arrow). $C$, High-power magnification of a semithin section of a large neuron in the riMLF of a monkey treated with GLY antiserum. Note the numerous GLY-immunoreactive terminals along the somata and proximal dendrite of the putative burst neuron (arrows). $D$, High-power magnification of labeled rip neurons from $A$ and $B$ (arrows). Scale bars: $A$ and $B, 300 \mu \mathrm{m} ; C$ and $\mathrm{D}=20 \mu \mathrm{m}$.

small size of the terminals prevented any definite conclusion at the light microscopic level. In addition, the axons of the transversely cut predorsal bundle lying adjacent to rip displayed strong GLU immunoreactivity, but were negative for GLY and GABA.

\section{Retrograde labeling with ${ }^{3} \mathrm{H}$-glycine and $W G A-H R P$}

In order to identify the neuronal projections to the riMLF, a case with a large unilateral WGA-HRP injection into the riMLF, comparable to the ${ }^{3} \mathrm{H}-\mathrm{GLY}$ injection (see below), was plotted (Fig. 7). A detailed description of projections to the riMLF is beyond the scope of this study, so only the localization of ret- rogradely filled cells is summarized in Table 2 . The rip neurons, ventral to VI, were strongly labeled, with a contralateral predominance.

The ${ }^{3} \mathrm{H}-\mathrm{GLY}$ injection site, which was placed in the caudal riMLF, displayed a central necrotic area located beneath the riMLF, probably due to damage made by the large pressure injection or the tip of the glass micropipette (Fig. $7 A, B$ ). Since this damage did not involve the riMLF itself, transmitter uptake within the termination area of OPNs in the riMLF should not have been affected. The estimated uptake area involved the whole extent of riMLF and the underlying mesencephalic retic- 
ular formation, the interstitial nucleus of Cajal (iC), and the zona incerta. There was no spread of ${ }^{3} \mathrm{H}-\mathrm{GLY}$ to the contralateral side. Within the halo of the injection site dense silver grain accumulations were observed over neurons of the oculomotor nucleus, the zona incerta, the nucleus ruber (rn), and mesencephalic tegmentum lateral to $\mathrm{iC}$. This cell labeling was thought to be due to nonspecific uptake by neurons in the vicinity of the injection site (Hökfelt and Ljungdahl, 1975). Since background levels of the silver grain density were achieved at levels caudal to the oculomotor nucleus, the analysis was restricted to brainstem regions caudal to the trochlear nucleus. About $9 \mathrm{~mm}$ caudal to the injection site the strongest retrograde labeling was found overlying the Nissl-stained cell bodies in the rip. The labeling was bilateral with a slight contralateral predominance (Fig. $8 A, B, D$ ). About $70 \%$ of rip neurons were labeled following the WGA-HRP injection in to the riMLF, compared with $50 \%$ of all rip neurons labeled after ${ }^{3} \mathrm{H}-\mathrm{GLY}$ injection. The silver grain accumulations, indicating ${ }^{3} \mathrm{H}-\mathrm{GLY}$ uptake, were restricted to neurons or cell parts in the upper surface of the sections. Therefore, the labeling of only $50 \%$ of rip neurons was attributed to the short radiation length $(2 \mu \mathrm{m})$ of tritium in the $40-\mu \mathrm{m}$-thick sections. In addition, labeled neurons were found in the contralateral reticular formation lateral to the nucleus reticularis pontis oralis (nrpo), and in the ipsilateral superior vestibular nucleus (sv). A few labeled large cells were scattered in the ipsilateral caudal reticular formation at the pontomedullary border (Table 2).

In both cases we observed similar patterns of anterograde WGA-HRP and ${ }^{3} \mathrm{H}$-GLY labeling of fibers descending down the brainstem. Termination patterns were seen in the cell groups of the paramedian tract (pmt) (Büttner-Ennever 1992) (see open arrow, Fig. $8 A$ ), in the marginal zone between the nucleus prepositus hypoglossi and the medial vestibular nucleus ( $m v$ ) ipsilaterally, the ipsilateral inferior olive, and the contralateral nucleus reticularis lateralis.

\section{Discussion}

In this study we suggest that PAV immunolabeling is a useful histological marker for the saccadic OPNs in the monkey, cat, and human. In addition, this is the first neuroanatomical study that directly identifies and quantifies the transmitters that are associated with OPNs, and shows with diverse methods that they utilize GLY as a neurotransmitter.

\section{$P A V$ immunolabeling of $O P N S$}

The neurons in rip contained high levels of the calcium-binding protein PAV, which appears to be associated with fast-firing neurons and cells with high oxidative metabolism (for review, see Celio, 1990; R. F. Spencer, personal communication). We considered the PAV-immunoreactive neurons in rip as OPNs for following reasons: virtually all neurons composing the bilaminar cell column of rip are PAV immunoreactive, and physiological studies indicate that OPNs are arranged in a compact cell group, which corresponds to rip (Büttner-Ennever et al., 1988), and that rip consists mainly of OPNs (Langer and Kaneko, 1990). The PAV expression is in line with the elevated energy consumption shown by the strong cytochrome oxidase activity in OPNs (Büttner-Ennever et al., 1988) and their high level of tonic activity, which often exceeds 100 spikes/sec in the monkey. These results consolidate the concept that the rip is a functional entity consisting mainly of OPNs (Büttner-Ennever et al., 1988; Langer and Kaneko, 1990), and differs from the neighboring raphe nuclei (Pecci Saavedra et al., 1983) by its characteristic association with PAV and the lack of 5-HT immunoreactivity. In cats, neither the location of this PAV-immunolabeled cell group nor the cytoarchitectural features are so clear and strictly organized as in monkey. However, the labeled cells correspond to the region of OPN recording sites (Evinger et al., 1982; Ohgaki et al., 1987; Strassman et al., 1987) and are coextensive with the retrogradely labeled cells resulting from riMLF injections (Ohgaki et al., 1989). In addition, the morphological description of single OPNs following intracellular HRP injection (Ohgaki et al., 1987) matches the anatomical features of our PAV-immunopositive putative OPNs. In human, the PAV-immunolabeled neurons within the medial part of the nrpc in this study correspond with those labeled for cytochrome oxidase activity (Büttner-Ennever et al., 1988). They were confined to the medial division of nrpc in Olszewski and Baxter (1954) and could clearly be delineated from the adjacent rostrolateral nrpe region.

\section{OPNs are glycinergic}

Three independent neuroanatomical methods provided evidence that OPNs use GLY as neurotransmitter: (1) OPNs are GLY immunoreactive; (2) OPNs were selectively back labeled with ${ }^{3} \mathrm{H}-\mathrm{GLY}$ from the riMLF; and (3) OPNs lack GABA/GAD immunoreactivity and GAD mRNA.

GLY immunoreactivity. Despite the relatively moderate GLY immunoreactivity of the OPNs, the labeling was considered to be significant for several reasons. First, preabsorption controls for the GLY antibody abolished all immunolabeling of terminals, axons, and cell bodies, indicating that the antibody recognizes GA-fixed GLY. Second, GLY immunostaining also was weak in other neuronal populations, which were proved glycinergic by independent methods, for example, saccadic IBNs of the horizontal system (Spencer et al., 1989) and in subnuclei of the superior olive (Helfert et al., 1989; Bledsoe et al., 1990).

Although GLY, like GLU, is used as metaholic intermediate by all cells, GLY immunoreactivity has been considered as a valid marker for GLY-releasing neurons because there is a greater difference between transmitter and metabolic pools compared to GLU. Quantitative electron microscope postembedding immunogold studies demonstrated that significantly high GLY concentrations were found only in cell bodies of GLY-releasing neurons, whereas GLU immunoreactivity was present in many putative glutaminergic and nonglutaminergic neurons at various levels (Ottersen, 1989a,b). An extensive discussion on this topic is given by Walberg et al. (1990). As a result we considered only the selective GLY immunolabeling of the OPN somata as functionally significant, but ignored the GLU immunoreactivity of OPN cell bodies, since it appeared ubiquitous.

A possible light cross-reactivity of the GLY antibody with fixed GABA, as reported by the manufacturing company, did not prove to be a major problem, because we did not observe any GLY immunolabeling in known GABAergic cells. Besides, our study demonstrated that there is no cross-reacting GABA in OPNs (see below).

Selective GLY uptake. The GLY immunoreactivity of OPNs was substantiated by their selective retrograde labeling after ${ }^{3} \mathrm{H}-$ GLY injection into the riMLF. This method has been successfully used to demonstrate the glycinergic nature of several projections (Spencer et al., 1989; Saint-Marie and Baker, 1990). It is based on the specific high-affinity uptake of GLY, exclusively by terminals of glycinergic neurons, and its subsequent rapid 
retrograde transport back to the cell bodies of origin (Hökfelt and Ljungdahl, 1975; Hunt et al., 1977). In our study the presence of GLY-releasing terminals within the riMLF was indicated by the abundance of GLY-immunoreactive puncta encircling the somata and proximal dendrites of large neurons (Fig. $8 C$ ), presumably vertical saccadic "burst neurons" Büttncr-Ennever and Büttner, 1978; Horn, unpublished observations). The specificity of the retrograde labeling was demonstrated by comparing the distribution of ${ }^{3} \mathrm{H}-\mathrm{GLY}$-labeled neurons to that of WGA-HRP neurons, similarly labeled after riMLF injections. Both injection sites, ${ }^{3} \mathrm{H}$-GLY and WGA-HRP, were large, ensuring sufficient back labeling of the OPNs from the riMLF. Spread into adjacent areas could be ignored, since none of these receive inputs from the OPN region (Büttner-Ennever and Büttner, 1978). The OPNs lie far enough away from the injection site $(9 \mathrm{~mm})$ that we were confident that the retrograde labeling of the OPNs with ${ }^{3} \mathrm{H}-\mathrm{GLY}$ was not due to local unspecific lowaffinity uptake, which was observed in some regions near the ${ }^{3} \mathrm{H}-\mathrm{GLY}$ injection site. Considering all areas containing WGAHRP-labeled neurons (see Table 2), retrograde ${ }^{3} \mathrm{H}-\mathrm{GLY}$ cell labeling was observed only in the rip, in the ipsilateral sv, scattered in the pontomedullary reticular formation (medrf), and in a cell group lateral to nrpo. Notably, no ${ }^{3} \mathrm{H}-\mathrm{GLY}$-labeled cells were found in either the deep layers of the sc, which send an excitatory projection to the ipsilateral riMLF (Harting et al., 1980; Nakao et al., 1992), or the mv, which provides an excitatory contralateral projection to the $\mathrm{iC}$ and caudal riMLF (Bütner-Ennever and Büttner, 1978). The anterograde ${ }^{3} \mathrm{H}-\mathrm{GLY}$ labeling was identical to the WGA-HRP labeling, and attributed to unspecific low-affinity uptake by cell bodies in the injection site (see discussion in Benson and Potashner, 1990). I ike other amino acids, for example, leucine, GLY appears to be actively taken up by all cell somata in a nonselective fashion, incorporated into proteins, and transported anterogradely. The anterograde labeling pattern did not interfere with the selective retrograde cell labeling.

In situ hybridization. In our study the negative GABA/GAD immunolabeling of the OPNs was confirmed by the lack of any detectable level of $\mathrm{GAD}_{67}$ mRNA shown by in situ hybridization. In contrast to local interneurons, lightly active large GABAergic neurons with far reaching projections may not accumulate any appreciable level of GABA/GAD in the cell bodies detectable by immunocytochemical methods. GABA/GAD is immediately transported away to the axon terminals, which always display a strong immunorcactivity. The detcction of GAD mRNA expression by in situ hybridization can overcome this problem, since the GAD encoding mRNA is largely confined to the cell body. Using in situ hybridization in the cat, large pretectogeniculate projection neurons have been identified as GAD mRNA expressing (Wahle et al., in press), although being GAD and GABA immunonegative in other studies (Nabors and Mize, 1991). The possibility that the OPNs might contain a GAD isoform, which is not detected by our probe, cannot be excluded fully, but appears unlikely. So far, the distribution of GABA-immunolabeled and $\mathrm{GAD}_{67}$ mRNA-expressing neurons appears to be similar, and indicates the predominance of this GAD isoform in the adult monkey brainstem. We would have preferred to confirm the glycinergic nature of OPNs directly with in situ hybridization, but to date no specific probes for enzymes in the GLY synthesis pathway are available.

The inhibitory effect of OPNs on saccadic burst neurons was first proposed by Keller (1974), who found that microstimula- tion of the OPN area in monkey eliminated saccades in all directions, or the saccades were transiently interrupted in midflight (Evinger et al., 1977). Simultaneous microstimulation of the OPNs, and extra- and intracellular recording of saccadic burst neurons in the IBN and excitatory burst neuron (EBN) area (Nakao et al., 1980; Furuya and Markham, 1982; Curthoys et al., 1984) and in the riMLF in the cat (Nakao et al., 1988, 1989), provided direct evidence for the inhibitory action of OPNs on saccadic burst neurons at monosynaptic latencies.

Taken together, our neuroanatomical findings strongly suggest that the inhibition of OPNs on saccadic burst neurons is mediated by the neurotransmitter GLY, and not by GABA.

\section{Transmitter inputs of OPNS}

Using immunocytochemistry, we identified monoaminergic and amino acid transmitters in terminal-like structures on OPNs that presumably control the level of neuronal activity.

Monoamines. We observed only a few 5-HT-positive and TH-positive varicosities contacting the somata of putative OPNs, although we were not able to study the terminal supply of the distal dendrites in our preparations without intracellular staining of the OPNs. Pharmacologically, a strong effect of 5-HT on OPN activity was demonstrated in the cat (Baloh et al., 1982; Ashikawa et al., 1991; Furuya et al., 1992). After systemic or local iontophoretic application of 5-HT, the authors describe a complete suppression of the tonic OPN firing rate. This suppression was abolished by an initial intravenous injection of methysergide, a 5-HT blocker. The discrepancy between the strong effect of 5-HT on OPNs and their low number of contacting 5-HT-immunoreactive varicosities could have several reasons: it is well known that serotoninergic neurons act either through specialized synaptic contacts, or they release the transmitter from varicosities without synaptic junctions on their targets, in a "hormone-like" fashion (for review, see Jacobs and Azmitia, 1992). This, or the presence of serotoninergic contacts on the distal dendrites of OPNs, might explain the strong effect of 5-HT. So far no pharmacological data are available on the effect of catecholamines on OPNs. Anatomically described projections from the rm, rd (Ito et al., 1984; Langer and Kaneko, 1990), and the locus coeruleus (Ito et al., 1984) might constitute the origin of serotoninergic and noradrenergic fibers contacting the OPNs.

$G$ ABAergic and glycinergic inputs. The equally dense distribution of GABA- and GLY-immunoreactive puncta on the somata and proximal dendrites of putative OPNs indicated a strong input from GABAergic and glycinergic terminals. Surprisingly, Furuya and coworkers did not find a significant effect after iontophoretic application of GLY, and only two out of eight tested OPNs were suppressed following GABA administration (Ashikawa et al., 1991; Furuya et al., 1992). This poor correlation with our anatomical findings might be due to various reasons. First, the immunostained profiles at the OPNs seen with light microscopy do not establish direct monosynaptic contacts. This is considered unlikely, but additional ultrastructural studies or the demonstration of GLY or GABA receptors at the OPNs are required to prove that issue. Second, since in the iontophoretic studies extracellular recording techniques were used, it is possible that a direct effect of the applied drugs was not achieved or, alternatively, not detected. In contrast to the effective $5-\mathrm{HI}$ application in 79 out of 100 neurons, the authors tested much

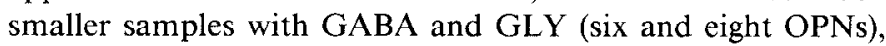
respectively, and an effect might have been missed. Third, not 
all their cells were OPNs. Theoretically, glycincrgic and/or GABAergic inpuls appear the most likely candidates for providing the brisk inhibition of the tonic OPN activity which triggers the saccade onset.

We can only speculate about possible sources of GABAergic and glycinergic afferents to OPNs; these pathways remain to be studied. Some models for saccade generation suggest that the saccadic IBNs produce the pause in OPNs prior to a saccade (Robinson, 1975). Theoretically the glycinergic IBNs of the horizontal system (Spencer et al., 1989) could be a source of GLY-immunoreactive terminals at the OPNs. But, despite the meticulous tracing of IBN axons in several studies, no direct monosynaptic projection of IBNs to the OPN area has ever been seen (Nakao et al., 1980; Strassman et al., 1986; Langer and Kaneko, 1990). The concept that saccades are initiated by a trigger signal from the sc was elaborated by Munoz and Guitton (1989), who suggested a modification of the saccade generator model. They proposed two functional inputs from the se to the OPNs: a direct excitatory projection from the "fixation zone" of the rostral sc, which would activate OPNs during fixation and thereby prevent saccades (Büttner-Ennever et al., 1988). Gaze shifts or saccades (Paré and Guitton, 1990) would be initiated by polysynaptic connections from the caudal sc via longlead burst neurons (LLBNs) that would in turn inhibit OPNs and produce the pause. Saccade-related LLBNs were found in the dorsal medullary reticular formation (Scudder et al., 1988), and in the rostral PPRF (Hepp and Henn, 1983) and nucleus reticularis tegmenti pontis (nrtp) (Crandall and Keller, 1985). All these areas reccive direct projections from the deep layers of the sc (Harting, 1977; Edwards and Henkel, 1978), and they project to OPNs in the monkey (Büttner-Ennever et al., 1988; Langer and Kaneko, 1990). Together, both pathways from the sc to the OPNs could explain the initial monosynaptic excitation of OPNs after sc stimulation that is followed by a polysynaptic inhibition (Raybourn and Keller, 1977). Therefore, functionally, GABAcrgic or glycinergic LLBNs could serve as the interneuron producing the inhibition in OPNs to initiate a saccade.

An additional possible inhibitory source of glycinergic and GABAergic afferents to OPNs might derive from vestibular neurons. Electrophysiological studies in the cal suggested a monosynaptic projection of inhibitory vestibular type II neurons to OPNs (Ito et al,, 1986). Although retrograde labeling in the vestibular nuclei was shown following HRP injections into the OPN region (Langer and Kaneko, 1990), this connection was not proved by more reliable anterograde tracing studies (Gerrits et al., 1985) or intracellular HRP injections of vestibular neurons (McCrea et al., 1987a,b).

Glutaminergic inputs. The severalfold higher concentration of GLU in putative GLU-releasing terminals, compared to that in other terminal types, is accepted as significant proof of their use of GLU as a neurotransmitter, whereas GLU immunolabeling of cell bodies may only reflect the presence of GLU in the metabolic pool (Liu et al., 1989; Otterson, 1989a,b). GLUimmunoreactive terminals were mainly concentrated on the dendrites of putative OPNs. In the monkey, OPNs receive a direct crossed projection from the deep layers of the rostral sc via the predorsal bundle (Büttner-Ennever ct al., 1988). Since the fibers of the predorsal bundle display GLU immunoreactivity and descend adjacent to OPNs, it appears feasible that the activation of OPNs onto their laterally oriented dendrites is mediated by glutaminergic projections from the sc. Excitatory projections to OPNs could also originate from areas in the frontal cortex that are involved in saccade generation. With ana- tomical tracing techniques, direct projections from the frontal eye fields (FEF) and the supplementary cyc ficlds (SEF) to the OPN region were demonstrated (Shook et al., 1988; Stanton et al. 1988).

Theoretically, saccadic disorders could be caused by malfunction of the OPNs. Based on the different models for saccade generation, OPN lesions could lead to saccadic oscillations (Zee and Robinson, 1979) or slow saccades (Scudder et al., 1988; Kaneko, 1989). Two findings support the latter hypothesis: first, no degeneration of OPNs was observed in two human cases with opsoclonus (Ridley et al., 1987); second, ibotenic acid lesions of the OPNs in the monkey resulted in slowing of saccades (Kaneko, 1992). Aiternatively, abnormal inputs to OPNs or saccadic burst neurons could be the cause of the saccadic disorders. A knowledge of the exact connectivity and the transmitters that control the neuronal elements of the saccadic burst generator could help to elucidate the cause for certain saccadic disorders in humans, for example, by combining neuropathoIogical analyses of the saccade generator in cases with saccadic disorders with a search for possible transmitter deficits.

In this article we have shown that OPNs are glycinergic, and the OPN somata in primates have GABAergic and glycinergic inputs, while GLU is confined to the dendrites. The complementary analysis of human rip in saccadic disorders remains to be investigated.

\begin{tabular}{|c|c|}
\hline \multicolumn{2}{|c|}{ Appendix } \\
\hline \multicolumn{2}{|c|}{ List of abbreviations } \\
\hline $5-\mathrm{HT}$ & serotonin \\
\hline $\mathrm{BC}$ & brachium conjunctivum \\
\hline $\mathrm{cd}$ & nucleus caudatus \\
\hline cs & rucleus centralis superior \\
\hline Dig & digoxigenin \\
\hline EBN & excitatory burst neuron \\
\hline $\mathrm{F}(\mathrm{ab})_{2}$ & antigen-binding fragment \\
\hline FEF & frontal eye fields \\
\hline $\mathrm{GA}$ & glutaraldehyde \\
\hline GABA & $\gamma$-aminobutyric acid \\
\hline $\mathrm{GAD}$ & glutamate decarboxylase \\
\hline (rit) & glutamate \\
\hline GLY & glycine \\
\hline IBN & inhibitory burst neuron \\
\hline $\mathrm{iC}$ & interstitial nucleus of Cajal \\
\hline KPBS & potassium phosphate-buffered saline \\
\hline ld & nucleus lateralis dorsalis \\
\hline $\lg , \mathrm{rl}$ & lateral geniculate nuclcus \\
\hline LLBN & long-lead burst neuron \\
\hline LNTB & lateral nucleus of the trapezoid body \\
\hline medrf & medullary reticular formation \\
\hline MLF & medial longitudinal fasciculus \\
\hline MNTB & medial nucleus of the trapezoid body \\
\hline $\mathrm{mv}$ & medial vestibular nucleus \\
\hline NOT & nucleus of the optic tract \\
\hline nPC & nucleus of the posterior commissure \\
\hline nrpc & nucleus reticularis pontis caudalis \\
\hline nrpo & nucleus reticularis pontis oralis \\
\hline nrtp & nucleus reticularis tegmenti pontis \\
\hline NVI & abducens nerve \\
\hline OPN & omnipause neuron \\
\hline $\mathrm{PAV}$ & parvalbumin \\
\hline $\mathrm{PB}$ & phosphate buffer \\
\hline PFA & paraformaldehyde \\
\hline pmt & a cell group of the paramedian tracts \\
\hline PPRF & paramedian pontine reticular formation \\
\hline $\mathrm{rd}$ & nucleus raphe dorsalis \\
\hline riMLF & rostral interstitial nucleus of the MLF \\
\hline rip & nucleus raphe intcrpositus \\
\hline $\mathrm{rm}$ & nucleus raphe magnus \\
\hline $\mathrm{rn}$ & nucleus ruber \\
\hline $\mathrm{rp}$ & nucleus raphe pontis \\
\hline
\end{tabular}


Sc superior colliculus

SEF supplementary eye fields

sg nucleus supragenualis

sn substantia nigra

SSC saline-sodium citrate

st nucleus subthalamicus

sv superior vestibular nucleus

TBS Tris-buffered saline

TH tyrosine hydroxylase

TR tractus retroflexus

VI abducens nucleus

VNTB ventral nucleus of the trapezoid body

\section{References}

Ashikawa H, Furuya N, Yabe T (1991) Effects of serotonin, GABA and glycine on the activity of pause neurons during vestibular nystagmus in the cat. Acta Otolaryngol (Stockh) 111:999-1005.

Baloh RW, Markham CH, Furuya N (1982) Inhibition of pontine omnipauser neurons in the cat by 5-hydroxytryptophan. Exp Neurol 76:586-593

Benson CG, Potashner SJ (1990) Retrograde transport of [ $\left.{ }^{3} \mathrm{H}\right]$ glycine from the cochlear nucleus to the superior olive in the guinea pig. $J$ Comp Neurol 296:415-426.

Bigbee JW, Kosek JC, Eng LF (1977) Effects of primary antiserum dilution on staining of "antigen-rich" tissues with the peroxidase antiperoxidase technique. J Histochem Cytochem 25:443-447.

Bledsoe SC Jr, Snead SR, Helfert RH, Prasad V, Wenthold RJ, Altschuler RA (1990) Immunocytochemical and lesion studies support the hypothesis that the projection from the medial nucleus of the trapezoid body to the lateral superior olive is glycinergic. Brain Res 517: $189-194$.

Büttner-Ennever JA (1992) Paramedian tract cell groups: a review of connectivity and oculomotor function. In: Vestibular and brain stem control of eye, head and body movements (Shimazu H, Shinoda Y, eds), pp 323-330. Basel: Japan Science Society, Karger.

Büttner-Ennever JA, Büttner U (1978) A cell group associated with vertical eye movements in the rostral mesencephalic reticular formation of the monkey. Brain Res 151:31-47.

Büttner-Ennever JA, Büttner U (1988) The reticular formation. In: Neuroanatomy of the oculomotor system (Büttner-Ennever JA, ed), pp 119-176. Amsterdam: Elsevier.

Büttner-Ennever JA, Cohen B, Pause M, Fries W (1988) Raphe nucleus of the pons containing omnipause neurons of the oculomotor system in the monkey, and its homologue in man. J Comp Neurol 267:307-321.

Celio MR (1990) Calbindin and parvalbumin in the rat nervous system. Neuroscience 35:375-475.

Crandall WF, Keller EL (1985) Visual and oculomotor signals in nucleus reticularis tementi pontis in alert monkey. J Neurophysiol 54: $1326-1345$

Curthoys IS, Markham CH, Furuya N (1984) Direct projection of pause neurons to nystagmus related excitatory burst neurons in the cat pontine reticular formation. Exp Neurol 83:414-422.

Edwards SB, Henkel CK (1978) Superior colliculus connections with the extraocular motor nuclei in the cat. J Comp Neurol 179:451-468.

Evinger C, Kaneko CRS, Johanson GW, Fuchs AF (1977) Omnipauser cells in the cat. In: Developmental neuroscience, Vol 1, Control of gaze by brain stem neurons (Baker R, Berthoz A, eds), pp 337-440. Amsterdam: Elsevier/North-Holland.

Evinger C, Kaneko CRS, Fuchs AF (1982) The activity of omnipause neurons in alert cats during saccadic eye movements and visual stimuli. J Neurophysiol 47:827-844.

Fuchs AF, Kaneko CRS, Scudder SA (1985) Brainstem control of saccadic eye movements. Annu Rev Neurosci 8:307-337.

Furuya N, Markham CH (1982) Direct inhibitory synaptic linkage of pause neurons with burst inhibitory neurons. Brain Res 245:139-143.

Furuya N, Yabe T, Ashikawa H, Koizumi T (1992) Neurotransmitters regulating the activity of nystagmus-related brain stem neurons in the cat. In: Vestibular and brain stem control of eye, head and body movements (Shimazu H, Shinoda Y, eds), pp 167-176. Basel: Japan Science Society, Karger.

Gerrits NM, Voogd J, Magras IN (1985) Vestibular nuclear efferents to the nucleus raphe pontis, the nucleus reticularis tegmenti pontis and the nuclei pontis in the cat. Neurosci Lett 54:357-362.

Harting JK (1977) Descending pathways from the superior colliculus: an autoradiographic analysis in the rhesus monkey (Macaca mulatta). J Comp Neurol 173:583-612.

Harting JK, Huerta M, Frankfurter A, Strominger L, Royce GJ (1980) Ascending pathways from the monkey superior colliculus: an autoradiographic analysis. J Comp Neurol 192:853-882.

Helfert RH, Bonneau JM, Wenthold RJ, Altschuler RA (1989) GABA and glycine immunoreactivity in the guinea pig superior olivary complex. Brain Res 501:269-286.

Hepp K, Henn V (1983) Spatio-temporal recording of rapid eye movement signals in the monkey paramedian pontine reticular formation (PPRF). Exp Brain Res 52:105-120.

Hepp K, Henn V, Vilis T, Cohen B (1989) Brainstem regions related to saccade generation. In: The neurobiology of saccadic eye movements (Wurtz RH, Goldberg ME, eds), pp 105-212. Amsterdam: Elsevier.

IIökfelt T, Ljungdahl $\AA$ (1975) Uptake mechanisms as a basis for the histochemical identification and tracing of transmitter-specific neuron populations. In: The use of axonal transport for studies of neuronal connectivity (Cowan WM, Cuenod M, eds), pp 249-305. Amsterdam: Elsevier.

Hunt SP, Streit P, Künzle H, Cuenod M (1977) Characterization of the pigeon isthmo-tectal pathway by selective uptake and retrograde movement of radioactive compounds and by Golgi-like horseradish peroxidase labeling. Brain Res 129:197-212.

Ito J, Markham CH, Curthoys IS (1984) Projection to eye movementrelated pause neuron region in cat using HRP. Exp Neurol 86:93104.

Ito J, Markham CH, Curthoys IS (1986) Direct projection of type II vestibular neurons to eye movement-related pause neurons in the cat pontine reticular formation. Exp Neurol 91:331-342.

Jacobs BL, Azmitia EC (1992) Structure and function of the brain serotonin system. Physiol Rev 72:165-229.

Kaneko CRS (1989) Hypothetical explanation of selective saccadic palsy caused by pontine lesion. Neurology 39:994-995.

Kaneko CRS (1992) Tests of two models of the neural saccade generator: saccadic eye movement deficits following lesions of the nuclei raphe interpositus and prepositus hypoglossi in monkey. In: Vestibular and brain stem control of eye, head and body movements (Shimazu H, Shinoda Y, eds), pp 125-135. Basel: Japan Science Society, Karger.

Kaufman DL, McGinnis JF, Krieger NR, Tobin AJ (1986) Brain glutamate decarboxylase cloned in lambda gt-11: fusion protein produces gamma-aminobutyric acid. Science 232:1138-1140.

Keller LL (1974) Participation of medial pontine reticular formation in eye movement generation in monkey. J Neurophysiol 37:316-332.

King WM, Precht W, Dieringer N (1980) Afferent and efferent connections of cat omnipause neurons. Exp Brain Res 38:395-403.

Kosaka T, Nagatsu I, Wu JY, Hama K (1986) Use of high concentrations of glutaraldehyde for immunocytochemistry of transmittersynthesizing enzymes in the central nervous system. Neuroscience 18: 975-990.

Langer TP, Kaneko CRS (1983) Efferent projections of the cat ocuionotor reticular omnipause neuron region: an autoradiographic study. J Comp Neurol 217:288-306.

Langer TP, Kaneko CRS (1990) Brainstem afferents to the oculomotor omnipause neurons in monkey. J Comp Neurol 295:413-427.

Liu CJ, Grandes P, Matute C, Cuenod M, Streit P (1989) Glutamatelike immunoreactivity revealed in rat olfactory bulb, hippocampus and cerebellum by monoclonal antibody and sensitive staining method. Histochemistry 90:427-445.

McCrea RA, Strassman A, May E, Highstein SM (1987a) Anatomical and physiological characteristics of vestibular neurons mediating the horizontal vestibuloocular reflex in the squirrel monkey. J Comp Neurol 264:547-570.

McCrea RA, Strassman A, May E, Highstein SM (1987b) Anatomical and physiological characteristics of vestibular neurons mediating the vertical vestibuloocular reflex in the squirrel monkey. J Comp Neurol 264:571-594:

Munoz DP, Guitton D (1989) Fixation and orientation control by the tecto-reticulo-spinal system in the cat whose head is unrestrained. Rev Neurol (Paris) 145:567-579.

Nabors LB, Mize RR (1991) A unique ncuronal organization in the cat pretectum revealed by antibodies to the calcium-binding protein calbindin-D 28K. J Neurosci 11:2460-2476.

Nakao S, Curthoys IS, Markham CH (1980) Direct inhibitory projection of pause neurons to nystagmus-related pontomedullary reticular burst neurons in the cat. Exp Brain Res 40:283-293. 
Nakao S, Shiraishi Y, Oda H, Inagaki M (1988) Direct inhibitory projection of pontine omnipause neurons to burst neurons in the Forel's field $\mathrm{H}$ controlling vertical eve movement-related motoneurons in the cat. Exp Brain Res 70:632-636.

Nakao S, Shiraishi Y, Inagaki M, Adachi S, Oda H, Oikawa T (1989) Direct inhibitory synaptic connections of pontine omnipause neurons with burst neurons in Forel's field $\mathrm{H}$ related to vertical saccades in the cat. Neurosci Lett 104:77-82.

Nakao S, Shiraishi Y, Li W (1992) Pontine and collicular inputs to Forel's field neurons generating vertical saccades in the alert cat. In: Vestibular and brain stem control of eye, head and body movements (Shimazu H, Shinoda Y, eds), pp 183-196. Basel: Japan Science Socicty, Karger.

Ohgaki T, Curthoys IS, Markham CH (1987) Anatomy of physiologically identified eye-movement-related pause neurons in the cat: pontomedullary region. J Comp Neurol 266:56-72.

Ohgaki T, Markham CH, Schneider JS, Curthoys IS (1989) Anatomical evidence of the projection of pontine omnipause neurons to midbrain regions controlling vertical eye movements. J Comp Neurol 289:610-625.

Olszewski J, Baxter D (1954) Cytoarchitecture of the human brain stem, $2 \mathrm{~d}$ ed. Basel: Karger.

Ottersen OP (1989a) Postembedding immunogold labelling of fixed glutamate: an electron microscopic analysis of the relationship between gold particle density and antigen concentration. J Chem Neuroanat $2: 57-66$

Ottersen OP (1989b) Quantitative electron microscopic immunocy tochemistry of amino acids. Anat Embryol (Berl) 180:1-15.

Paré M. Guitton D (1990) Gaze-related activity of brainstem omnipause neurons during combined eye-head gaze shifts in the alert cat. Exp Brain Res 83:210-214.

Pecci Saavedra J, Pasik T, Pasik P (1983) Immunocytochemistry of serotoninergic neurons in the central nervous system of monkeys. In: Neural transmission, learning and memory (Caputto R, Ajmone Marsan C, eds), pp 81-96. New York: Raven.

Raybourn MS, Keller EL (1977) Colliculoreticular organization in primate oculomotor system. J Neurophysiol 40:861-878.

Ridley A, Kennard C, Scholtz CL, Büttner-Ennever JA, Summers B, Turnbull A (1987) Omnipause neurons in two cases of opsoclonus associated with oat cell carcinoma of the lung. Brain 110:1699-1709.

Robinson DA (1975) Oculomotor control signals. In: Basic mechanisms of ocular motility and their clinical implications (Lennerstrand G, Bach-y-Rita P, eds), pp 337-374. Oxford: Pergamon.

Saint-Marie RL, Baker RA (1990) Neurotransmitler-specific uptake and retrograde transport of $\left[{ }^{3} \mathrm{H}\right]$ glycine from the inferior colliculus by ipsilateral projections of the superior olivary complex and nuclei of the lateral lemniscus. Brain Res 524:244-253.

Scudder CA, Fuchs AF, Langer TP (1988) Characteristics and functional identification of saccadic inhibitory burst neurons in the alert monkey. J Neurophysiol 59:1430-1454.

Shanta TR, Manocha SL, Bourne GH (1968) A stereotaxic atlas of the Java monkey brain. Basel: Karger.

Shook BL, Schlag-Rey M, Schlag J (1988) Direct projection from the supplementary eye field to the nucleus raphe interpositus. Fxp Brain Res 73:215-218.

Spencer RF, Wenthold RJ, Baker R (1989) Evidence for glycine as an inhibitory neurotransmitter of vestibular reticular, and prepositus hypoglossi neurons that project to the cat abducens nucleus. J Neurosei $9: 2718-2736$

Stantun GB, Goldberg ME, Bruce CJ (1988) Frontal eye field efferents in the macaque monkey. II. Topography of terminal fields in midbrain and pons. J Comp Neurol 271:493-506.

Strassman A. Highstein SM. McCrea RA (1986) Anatomy and physiology of saccadic burst neurons in the alert squirrel monkey. II Inhibitory burst neurons. J Comp Neurol 249:337-357.

Strassman A, Evinger C, McCrea RA, Baker RG, Highstein SM (1987) Anatomy and physiology of intracellularly labelled omnipause neurons in the cat and squirrel monkey. Exp Brain Res 67:436-440.

Taber E, Brodal A, Walberg F (1960) The raphe nuclei of the brain stem in the cat. I. Normal topography and cytoarchitecture and gencral discussion. J Comp Neurol 114:161-188.

Vater M, Kössl M, Horn AKE (1990) Differential distribution of GABA and glycine in the ascending auditory pathway of horseshoe bats. In Brain-perception-cognition. Pruceedings of the 18 th Göltinger Neurobiologentagung (Elsner N, Roth G, eds), p 142. Stuttgart: Thieme

Wahle P, Beckh S (1992) A method of in situ hybridization combined with immunocytochemistry, histochemistry, and tract tracing to characterize the mRNA expressing cell types in heterogeneous neuronal populations. J Neurosci Methods 41:153-166.

Wahle P, Stuphorn V, Schmidt M, Hoffmann K-P (1993) LGN projecting neurons of the cat's pretectum express glutamic acid decarboxylase mRNA. J Eur Neurosci, in press.

Walberg F, Ottersen OP, Rinvik E (1990) GABA, glycine, aspartate, glutamate and taurine in the vestibular nuclei: an immunocytochemical investigation in the cat. Exp Brain Res 79:547-563.

Zee DS, Robinson DA (1979) A hypothetical explanation of saccadic oscillations. Ann Neurol 5:405-414. 